\title{
Assembly and Succession of Iron Oxide Microbial Mat Communities in Acidic Geothermal Springs
}

OPEN ACCESS

Edited by:

Tanja Bosak,

Massachusetts Institute of

Technology, USA

Reviewed by:

Susan Childers,

Colby College, USA

William D. Leavitt

Washington University in St. Louis,

USA

*Correspondence:

William P. Inskeep

binskeep@montana.edu

${ }^{\dagger}$ Present Address:

Jacob P. Beam,

Bigelow Laboratory for Ocean

Sciences, East Boothbay, USA

Mark A. Kozubal,

Sustainable Bioproducts LLC.,

Bozeman, USA

Ryan deM. Jennings,

Mercer University, Macon, USA

Specialty section:

This article was submitted to Microbiological Chemistry and

Geomicrobiology,

a section of the journal

Frontiers in Microbiology

Received: 07 October 2015 Accepted: 11 January 2016

Published: 15 February 2016

Citation:

Beam JP, Bernstein HC, Jay ZJ, Kozubal MA, Jennings Rd, Tringe SG and Inskeep WP (2016) Assembly and

Succession of Iron Oxide Microbial Mat Communities in Acidic Geothermal Springs.

Front. Microbiol. 7:25

doi: 10.3389/fmicb.2016.00025

\author{
Jacob P. Beam ${ }^{1 \dagger}$, Hans C. Bernstein ${ }^{2,3}$, Zackary J. Jay ${ }^{1,2}$, Mark A. Kozubal ${ }^{1+}$, \\ Ryan deM. Jennings ${ }^{1+}$, Susannah G. Tringe ${ }^{4}$ and William P. Inskeep ${ }^{1 *}$ \\ 1 Department of Land Resources and Environmental Sciences, Thermal Biology Institute, Montana State University, \\ Bozeman, MT, USA, ${ }^{2}$ Department of Chemical and Biological Engineering, Center for Biofilm Engineering, Montana State \\ University, Bozeman, MT, USA, ${ }^{3}$ Biodetection Science and Biological Science Division, Pacific Northwest National \\ Laboratory, Richland, WA, USA, ${ }^{4}$ United States Department of Energy Joint Genome Institute, Walnut Creek, CA, USA
}

Biomineralized ferric oxide microbial mats are ubiquitous features on Earth, are common in hot springs of Yellowstone National Park (YNP, WY, USA), and form due to direct interaction between microbial and physicochemical processes. The overall goal of this study was to determine the contribution of different community members to the assembly and succession of acidic high-temperature $\mathrm{Fe}$ (III)-oxide mat ecosystems. Spatial and temporal changes in Fe(III)-oxide accretion and the abundance of relevant community members were monitored over 70 days using sterile glass microscope slides incubated in the outflow channels of two acidic geothermal springs $(\mathrm{pH}=3-3.5$; temperature $=68-75^{\circ} \mathrm{C}$ ) in YNP. Hydrogenobaculum spp. were the most abundant taxon identified during early successional stages (4-40 days), and have been shown to oxidize arsenite, sulfide, and hydrogen coupled to oxygen reduction. Iron-oxidizing populations of Metallosphaera yellowstonensis were detected within 4 days, and reached steady-state levels within 14-30 days, corresponding to visible Fe(III)-oxide accretion. Heterotrophic archaea colonized near 30 days, and emerged as the dominant functional guild after 70 days and in mature $\mathrm{Fe}$ (III)-oxide mats $(1-2 \mathrm{~cm}$ thick). First-order rate constants of $\mathrm{Fe}(\mathrm{III})$-oxide accretion ranged from 0.046 to 0.05 day $^{-1}$, and in situ microelectrode measurements showed that the oxidation of $\mathrm{Fe}(\mathrm{II})$ is limited by the diffusion of $\mathrm{O}_{2}$ into the $\mathrm{Fe}$ (III)-oxide mat. The formation of microterracettes also implicated $\mathrm{O}_{2}$ as a major variable controlling microbial growth and subsequent mat morphology. The assembly and succession of $\mathrm{Fe}$ (III)-oxide mat communities follows a repeatable pattern of colonization by lithoautotrophic organisms, and the subsequent growth of diverse organoheterotrophs. The unique geochemical signatures and micromorphology of extant biomineralized $\mathrm{Fe}(\mathrm{III})$-oxide mats are also useful for understanding other $\mathrm{Fe}(\mathrm{II})$-oxidizing systems.

Keywords: Hydrogenobaculum, Metallosphaera, lithoautotroph, organoheterotroph, archaea, biomineralization, oxygen 


\section{INTRODUCTION}

Microbial mat communities are ubiquitous geobiological features (e.g., stromatolites; Riding, 1999) in contemporary and past environments on Earth, are often stratified due to gradients in key geochemical constituents (e.g., oxygen; de Beer et al., 1994; Bernstein et al., 2013), and often leave biological signatures (biomarkers) preserved in the rock record (e.g., lipids; Peters and Moldowan, 1993). Biogeochemical stratification of microbial mats may produce distinct morphological features that can be preserved (e.g., iron formations and marine carbonates), and provide insights into past geochemical and hydrodynamic conditions (e.g., Kappler and Straub, 2005; Fouke, 2011). Microbial mat communities often produce extracellular polymeric substances (EPS), which may serve as sites for mineral nucleation and growth (e.g., Mann, 1988; Kandianis et al., 2008). Understanding mechanisms of assembly and succession in modern-day mat communities provides clues regarding past environmental conditions and biogeophysical controls that lead to the biomineralization of specific solid phases (Reid et al., 2000; Fouke, 2011). Moreover, modern microbial mat ecosystems can be observed in real-time and monitored over spatial and temporal scales to elucidate mechanisms of formation under various geochemical and hydrologic conditions.

Iron is the fourth most abundant element in the Earth's crust and is an essential cofactor in numerous proteins across all domains of life (e.g., iron-sulfur proteins). Microorganisms may also gain energy via the oxidation of $\mathrm{Fe}$ (II) to $\mathrm{Fe}$ (III) under aerobic or anaerobic conditions, which usually results in the precipitation of insoluble solid-phase Fe(III)-oxides (Konhauser, 1998, 2006; Kappler and Straub, 2005; Ehrlich and Newman, 2009; Emerson, 2012). The reduction of Fe(III)-oxides to Fe(II) can be coupled with the oxidation of inorganic (e.g., hydrogen) or organic (e.g., acetate) compounds by other microorganisms, completing the $\mathrm{Fe}$ cycle. Uncatalyzed abiotic rates of $\mathrm{Fe}(\mathrm{II})$ oxidation are extremely slow at $\mathrm{pH}$ values less than 4 (Singer and Stumm, 1970; Kappler and Straub, 2005); consequently, the deposition of Fe(III)-oxides under acidic conditions can often be attributed to the activity of $\mathrm{Fe}(\mathrm{II})$-oxidizing microbial populations. Low $\mathrm{pH}(<4)$ acid-mine drainage (Denef et al., 2010) and acidic geothermal springs in YNP (Langner et al., 2001; Kozubal et al., 2012) exhibit significant amounts of Fe(III)-oxide biomineralization.

High-temperature $\left(65-80^{\circ} \mathrm{C}\right)$, acidic $(\mathrm{pH}=2-3.5) \mathrm{Fe}(\mathrm{III})$ oxide microbial mats in Yellowstone National Park (YNP) represent hydrodynamically-controlled model systems for studying microbial interactions and biogeochemical processes in situ (Kozubal et al., 2008, 2012; Inskeep et al., 2010, 2013). Metallosphaera yellowstonensis (order Sulfolobales, Crenarchaeota) is the primary chemolithoautotroph responsible for $\mathrm{Fe}(\mathrm{II})$-oxidation in these systems, which results in the precipitation of copious amounts of $\mathrm{Fe}(\mathrm{III})$-oxides and/or jarosite, depending on spring geochemistry (Kozubal et al., 2008, 2012). Protein-coding genes responsible for Fe(II)oxidation in M. yellowstonensis (e.g., foxC) have been elucidated, and are highly expressed in Fe(III)-oxide microbial mats of YNP (Kozubal et al., 2011). Hydrogenobaculum spp. (order
Aquificales) are versatile chemolithoautotrophs that inhabit sulfur and iron-dominated acidic hot springs, and have been shown to utilize several different electron donors (e.g., As(III), $\mathrm{H}_{2}$, and $\mathrm{H}_{2} \mathrm{~S}$ ) coupled with the reduction of $\mathrm{O}_{2}$ to drive the fixation of $\mathrm{CO}_{2}$ via the reductive TCA cycle (DonahoeChristiansen et al., 2004; D'Imperio et al., 2007; Hamamura et al., 2009; Romano et al., 2013; Takacs-Vesbach et al., 2013). Hydrogenobaculum spp. and Metallosphaera yellowstonensis are both implicated as early colonizing populations (Macur et al., 2004) and carbon dioxide $\left(\mathrm{CO}_{2}\right)$ fixing organisms (Jennings et al., 2014) in high-temperature Fe(III)-oxide mats of YNP; however, the role of these lithoautotrophs in early stages of Fe(III)-oxide mat formation has not been elucidated.

Prior work using stable carbon isotopes $\left({ }^{13} \mathrm{C}\right)$ has shown that $\mathrm{CO}_{2}$-derived microbial $\mathrm{C}$ contributes a minimum of $40 \%$ of the total biomass $\mathrm{C}$ in mature $\mathrm{Fe}$ (III)-oxide mats (Jennings et al., 2014), which provides a significant organic C source for organoheterotrophic thermoacidophiles. Furthermore, Hydrogenobaculum spp. have also been shown to uptake radiolabeled bicarbonate $\left({ }^{14} \mathrm{CO}_{2}\right)$ in high sulfide zones of the same acidic geothermal springs (Boyd et al., 2009). Thus, the growth and assembly of early-colonizing lithoautotrophic populations (i.e., Hydrogenobaculum spp. and Metallosphaera yellowstonensis) will likely influence the subsequent succession and activity of organoheterotrophic organisms. Consequently, the primary objectives of the current study were to (i) determine the spatiotemporal dynamics of key community members involved in Fe(III)-oxide mat assembly in acidic geothermal springs of Norris Geyser Basin (YNP), (ii) quantify the amount of $\mathrm{Fe}(\mathrm{III})$-oxides accreted and oxygen consumed in situ as a function of time, (iii) monitor temporal changes in community composition using $16 \mathrm{~S}$ rRNA gene sequencing, and (iv) integrate laboratory measurements and field observations across different scales to develop a conceptual model of Fe(III)-oxide assembly and succession. A combination of geochemical, microscopic, and molecular methods were employed to reveal that Hydrogenobaculum spp. exhibit rapid growth rates in situ and are the first colonizers in high-temperature acidic Fe mats, followed by the accretion of Fe(III)-oxides due to the rise of $\mathrm{Fe}(\mathrm{II})$-oxidizing populations of Metallosphaera yellowstonensis. Other heterotrophic archaea, which include several novel groups and additional Crenarchaeota (e.g., Sulfolobales, Desulfurococcales) colonize at later stages of mat development and likely utilize organic $\mathrm{C}$ produced by lithoautotrophs. Distinct stages of mat development were associated with specific micromorphological features that provide a basis for understanding the assembly and succession of thermoacidic Fe(III)-oxide microbial mats.

\section{MATERIALS AND METHODS}

\section{Site Descriptions}

Two acidic geothermal springs in Norris Geyser Basin (NGB), YNP were chosen for this study based on long-term microbial and geochemical data obtained over the last 10-15 years (Jackson et al., 2001; Langner et al., 2001; Inskeep et al., 
2004, 2005, 2010, 2013; Macur et al., 2004; Inskeep and McDermott, 2005; Ackerman, 2006; Kozubal et al., 2008, 2012, 2013; Beam et al., 2014; Jay et al., 2014; Jennings et al., 2014), which provides an excellent biological and physicochemical context for integrating results from the current study. Discharge source waters of "Beowulf" Spring (Thermal Inventory Number NHSP035; Lat/Lon $=44.731519,-110.711357)$ and an unnamed spring in One Hundred Spring Plain (OSP) (referred to here and in prior studies as OSP; Thermal Inventory Number NHSP115; Lat/Lon $=44.733044,-110.709012)$ exhibit low $\mathrm{pH}$ values (3-3.5), high temperatures $\left(80-85^{\circ} \mathrm{C}\right)$ (Figure 1; Table 1), and contain reduced chemical species and high concentrations of dissolved inorganic carbon (DIC) formed by water-rock interactions occurring deep in the hydrothermal reservoir (Fournier, 1989). The concentrations of Fe(II), As(III), $\mathrm{H}_{2} \mathrm{~S}, \mathrm{H}_{2}$, and $\mathrm{CH}_{4}$ are significant and can potentially serve as electron donors for lithotrophic microbial populations (Macur et al., 2004; Inskeep et al., 2005; Kozubal et al., 2012). There is also an abundance of potential electron acceptors, which include $\mathrm{O}_{2}$, $\mathrm{SO}_{4}^{2-}, \mathrm{NO}_{3}^{-}, \mathrm{Fe}(\mathrm{III})$, and $\mathrm{As}(\mathrm{V})$ (Inskeep et al., 2005).

\section{Iron Accretion Rates}

Iron-oxide accretion rates were measured in situ by inserting acid washed $(2 \% \mathrm{HCl})$ and autoclaved borosilicate glass microscope slides $(2.5 \times 7.5 \mathrm{~cm})$ into the main outflow channels of OSP and Beowulf Springs (Figure 1). Glass slides were chosen for the growth substrate for multiple reasons: (1) they mimic the native siliceous sinter that these iron oxide mats grow on, (2) they are easy to clean and sterilize, (3) glass is inexpensive, and (4) they are easy to deploy and sample in the hot spring study sites. Slides were inserted and removed at various time points during four field seasons (2010-2013) with the most extensive sampling occurring in 2012-2013 (Table S1). The number of slides inserted at any time point $(\sim 6-8)$ was limited to a small area in the outflow channel that exhibited the desired physicochemical environment (temperature range $=70-75^{\circ} \mathrm{C}$ in

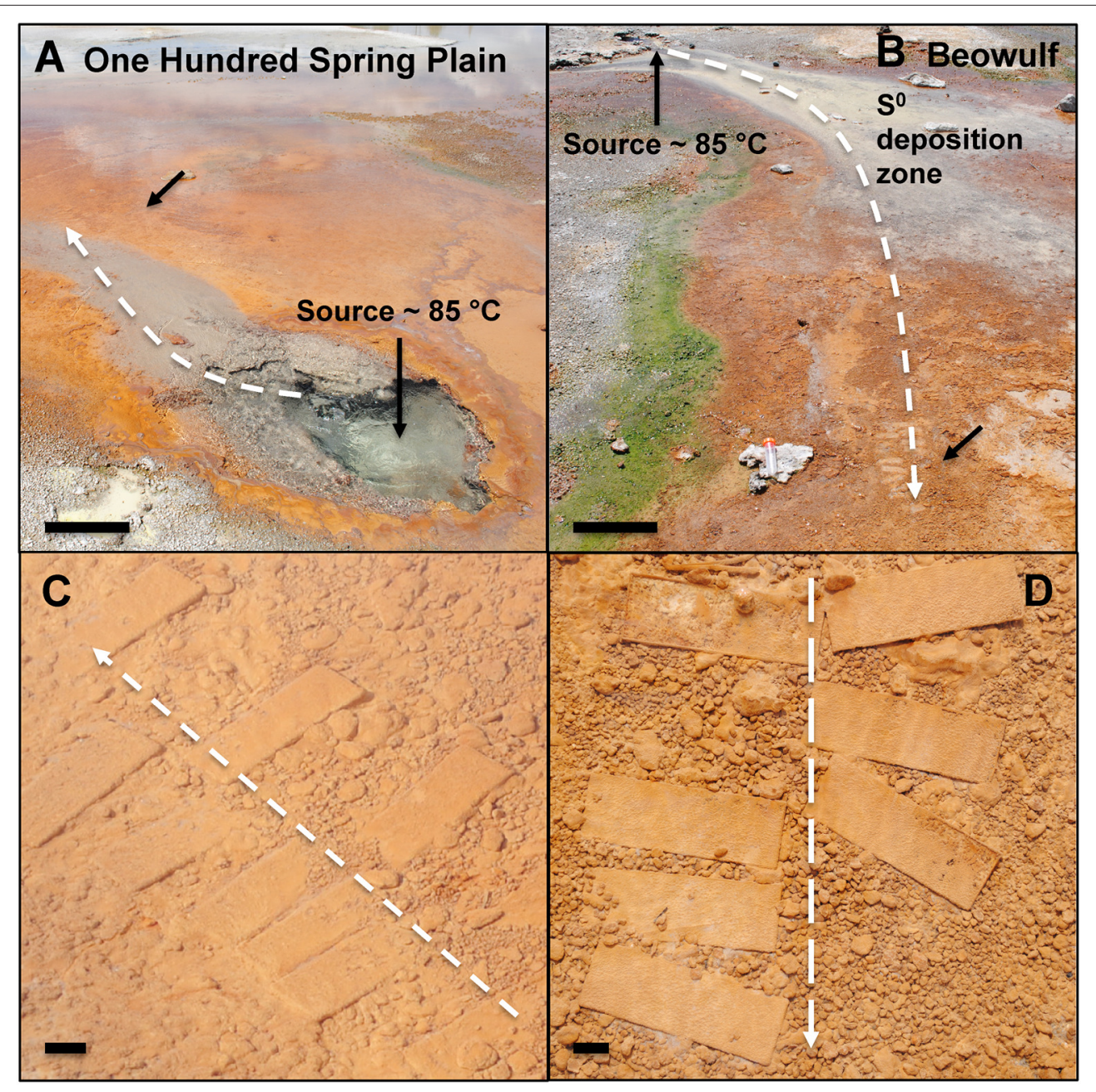

FIGURE 1 | Photographs of One Hundred Spring Plain (A) and Beowulf (B) Springs located in Norris Geyser Basin, Yellowstone National Park, WY, USA $($ scale bar $\mathbf{= 3 0} \mathbf{c m}$ ). The black arrows represent the approximate location of slide placement in the primary outflow channel. Glass slides incubated for 70 days in OSP (C) and Beowulf (D) Springs (scale bar $=1 \mathrm{~cm}$ ). The dashed white arrows represent direction of flow. 
TABLE 1 | Physical and geochemical parameters measured over four field seasons corresponding to in situ slide incubations.

\begin{tabular}{|c|c|c|c|c|c|c|c|c|c|c|}
\hline \multirow[t]{2}{*}{ Spring (Position) } & \multirow[t]{2}{*}{ Temperature $\left({ }^{\circ} \mathrm{C}\right)$} & \multirow[t]{2}{*}{$\mathrm{pH}$} & \multirow{2}{*}{$\begin{array}{l}\text { Channel velocity } \\
\left(\mathrm{cm} \mathrm{s}^{-1}\right)\end{array}$} & \multirow{2}{*}{$\begin{array}{l}\text { Reynolds } \\
\text { number }\end{array}$} & $\mathrm{O}_{2}(\mathrm{aq})$ & $\mathrm{Fe}$ (TS) & As (TS) & $\mathrm{CO}_{2}(\mathrm{aq})$ & DOC & $\mathrm{H}_{2}(\mathrm{aq})$ \\
\hline & & & & & \multicolumn{4}{|c|}{$\mu \mathbf{M}$} & & $\mathrm{nM}$ \\
\hline $\begin{array}{l}\text { One Hundred } \\
\text { Spring Plain (B) }\end{array}$ & $72.8(1.4)$ & $3.5(0.1)$ & $2-5$ & $1.5 \cdot 10^{3}$ & $33(11)$ & $25(7)$ & $24(6)$ & $100(40)$ & $109(55)$ & $39(40)$ \\
\hline Beowulf (D) & $67.6(1.8)$ & $2.9(0.1)$ & $20-30$ & $1.4 \cdot 10^{4}$ & $44(6)$ & $30(3)$ & $28(4)$ & $200(180)$ & $52(12)$ & $13(7)$ \\
\hline
\end{tabular}

Numbers in parentheses are equal to \pm 1 standard deviation from the mean.

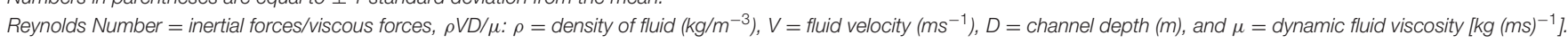
DOC, dissolved organic carbon.

OSP Spring and $65-70^{\circ} \mathrm{C}$ in Beowulf Spring). Inclusion of two different geothermal springs provided a direct comparison of general trends in iron accretion and deposition. Iron oxides were removed from glass slides using a razor blade, dried overnight at $70^{\circ} \mathrm{C}$, then transferred to $50 \mathrm{~mL}$ of $0.175 \mathrm{M}$ ammonium oxalate buffer $(\mathrm{pH}=3)$ to dissolve poorly-crystalline iron (oxyhydr)oxides (Loeppert and Inskeep, 1996). Slides without visible $\mathrm{Fe}(\mathrm{III})$-oxide deposition were placed directly into the $0.175 \mathrm{M}$ ammonium oxalate buffer. The extracting solutions were shaken (Model E600, Eberbach Co. Ann Arbor, MI, USA) for $\sim 2 \mathrm{~h}$ to promote $\mathrm{Fe}(\mathrm{III})$-oxide dissolution. All $\mathrm{Fe}$ oxalate extractions were filtered $(0.22 \mu \mathrm{m})$ into $15 \mathrm{~mL}$ Falcon $^{\mathrm{TM}}$ tubes, and analyzed for $\mathrm{Al}, \mathrm{Ag}, \mathrm{As}, \mathrm{Ba}, \mathrm{Be}, \mathrm{B}, \mathrm{Cd}, \mathrm{Ca}, \mathrm{Cr}$, Co, $\mathrm{Cu}, \mathrm{Fe}, \mathrm{P}, \mathrm{Pb}, \mathrm{Mg}, \mathrm{Mn}, \mathrm{Mo}, \mathrm{Na}, \mathrm{Ni}, \mathrm{K}, \mathrm{S}, \mathrm{Sb}, \mathrm{Se}, \mathrm{Si}$, $\mathrm{Sr}, \mathrm{Tl}, \mathrm{Ti}, \mathrm{V}, \mathrm{W}$, and $\mathrm{Zn}$ using inductively coupled plasmaoptical emission spectroscopy (OPTIMA 5300, Perkin-Elmer, Waltham, MA, USA). Rate constants of Fe(III)-oxide accretion were estimated in $\mathrm{R}$ using nonlinear least squares fits to the exponential growth rate equation $\mathrm{x}=\mathrm{x}_{\mathrm{o}} \mathrm{e}^{\mathrm{kt}}$, where $\mathrm{x}$ $=\mathrm{Fe}$ accreted $\left(\mu \mathrm{mol} \mathrm{cm} \mathrm{cm}^{-2}\right), \mathrm{x}_{\mathrm{o}}=$ initial Fe $\left(\mu \mathrm{mol} \mathrm{cm} \mathrm{cm}^{-2}\right)$, $\mathrm{k}=$ first-order rate constant $\left(\mathrm{day}^{-1}\right)$, and $\mathrm{t}=$ time (day). Different growth substrates including polyether ether ketone, titanium, polypropylene, polycarbonate, polytetrafluoroethylene, and ultra-high-molecular-weight polyethylene were also tested to determine if the rate of $\mathrm{Fe}$ (III)-oxide accretion on glass could also be observed on other substrates (substrates were deployed in Beowulf Spring from October 24 to November 6, 2013 (13 days) and total iron was measured as above (Figure S1).

\section{DNA Extraction}

DNA was extracted from slides grown over various time points to determine temporal microbial community composition. Biomass and mineralized iron oxides were removed from the slides by either scrapping off a known area with a sterile razor blade (when visible iron oxides were present), or by vortexing the slide in a $50 \mathrm{~mL}$ conical tube for $\sim 30 \mathrm{~s}$ containing a sterile solution (autoclaved and $0.22 \mu \mathrm{m}$ filtered) of $17.5 \mathrm{mM}$ ammonium oxalate buffer $(\mathrm{pH}=3)$, followed by cell collection on a $0.22 \mu \mathrm{m}$ filter. The direct extraction method was performed when there were no visible $\mathrm{Fe}$ (III)-oxides present, which was common for slides incubated for $<10$ days. DNA was extracted from scraped Fe(III)oxides or from cell-enriched filters using the FastDNA ${ }^{\mathrm{TM}}$ Spin Kit for Soil DNA extraction kit and protocol (MP Biomedicals, LLC, Solon, OH, USA). DNA was quantified using a Qubit ${ }^{\circledR}$
2.0 fluorometer and Qubit ${ }^{\circledR}$ dsDNA High Sensitivity Assay Kit (range 0.2-100 ng total dsDNA) (Life Technologies Co.). DNA quantification (expressed as ng DNA $\mathrm{cm}^{-2} \mathrm{day}^{-1}$ ) provided an estimate of biomass production as a function of time. Nonlinear model fits were generated in $\mathrm{R}$ as described above, where $\mathrm{x}$ and $\mathrm{x}_{\mathrm{O}}$ are equal to DNA concentrations $\left(\mathrm{ng} \mathrm{cm}^{-2}\right)$.

\section{Scanning Electron Microscopy}

Slides incubated in situ were also used for direct examination of microbial colonization with scanning electron microscopy. A subset of slides removed from the springs were fixed in $1 \%$ (final concentration) filter-sterilized $(0.22 \mu \mathrm{m})$ glutaraldehyde. A Zeiss SUPRA 55VP field emission scanning electron microscope (Image and Chemical Analysis Laboratory, Montana State University) was used to image colonized slide surfaces, which were sputter-coated with iridium to minimize charging at low voltage $(1 \mathrm{keV})$. Direct imaging of cells also provided estimates of in situ growth rates (3-5 random field views per estimate) on slides incubated for 4-15 days.

\section{Fluorescence In situ Hybridization}

Glass microscope slides with $0.3 \mathrm{~cm}^{2}$ round Teflon printed wells (SPI Supplies/Structure Probe, Inc. West Chester, PA, USA) were acid washed and autoclaved as above, incubated in situ for 6 days (October 24-30, 2013), removed and fixed with 1\% paraformaldehyde (final concentration) for $5 \mathrm{~min}$ at $4^{\circ} \mathrm{C}$. The fixative was removed from the slide by rinsing in a 1:1 solution of $1 \mathrm{X}$ phosphate buffered saline (PBS): 100\% ethanol (EtOH) and stored in a $50 \mathrm{~mL}$ canonical tube containing 1:1 1 X PBS: $100 \%$ $\mathrm{EtOH}$ at $-20^{\circ} \mathrm{C}$ until hybridization.

Slides were dehydrated in an increasing ethanol series of 50,80 , and $100 \%$ for $3 \mathrm{~min}$ each, and then air-dried at room temperature. Hybridization buffer containing 40\% formamide, $0.9 \mathrm{M} \mathrm{NaCl}, 20 \mathrm{mM}$ Tris HCL, and $0.1 \%$ sodium dodecyl sulfate was added to multiple wells $(30 \mu \mathrm{L})$ and $1 \mu \mathrm{L}$ of each probe (6-FAM labeled Aqi338, Kubo et al., 2011; Cy5 labeled Arch915, Stahl and Amann, 1991) was added directly to the hybridization buffer on the wells (probe working solutions were $50 \mathrm{ng} / \mu \mathrm{L}$ for 6 -FAM and $30 \mathrm{ng} / \mu \mathrm{L}$ for $\mathrm{Cy} 5$ ). The slide was placed in a $50 \mathrm{~mL}$ conical tube with tissue paper soaked in hybridization buffer $(\sim 1 \mathrm{~mL})$ and incubated for $1.5 \mathrm{~h}$ in a $46^{\circ} \mathrm{C}$ hybridization oven. The slide was then washed for exactly $10 \mathrm{~min}$ in buffer that was pre-warmed to $48^{\circ} \mathrm{C}$ containing $46 \mathrm{mM} \mathrm{NaCl}, 20 \mathrm{mM}$ Tris $\mathrm{HCl}$, and $5 \mathrm{mM}$ EDTA. The slide was then rinsed with room 
temperature distilled water and dried with laboratory air. The slide was then immediately visualized with a Leica SP5 inverted confocal scanning laser microscope (Leica Microsystems Inc., Buffalo Grove, IL, USA) at the Montana State University Center for Biofilm Engineering Confocal Microscopy Laboratory, or stored at $-20^{\circ} \mathrm{C}$ for up to $2-3$ days without fluorescence signal loss.

\section{Archaeal and Bacterial 16S rRNA Gene Illumina Sequencing and Analysis}

Archaeal and bacterial 16S rRNA gene sequences were amplified with the universal 515F (5'-GTG CCA GCM GCC GCG GTA A-3')/806R ( $5^{\prime}$-GGA CTA CHV GGG TWT CTA AT-3') (Caporaso et al., 2010) primer pair at the Department of EnergyJoint Genome Institute (Walnut Creek, CA, USA) and sequenced on an Illumina MiSeq (NCBI Bioproject ID PRJNA306640). A custom pipeline was utilized to screen Illumina Tag (iTag) $16 \mathrm{~S}$ rRNA gene sequences (average length $=250 \mathrm{bp}$ ) with a database of relevant $16 \mathrm{~S}$ rRNA gene sequences from YNP hot springs. Briefly, chimeras were removed from the iTag dataset, the sequences grouped into operational taxonomic units at $97 \%$ identity, then identified based on comparison to a curated group of long fragment (>1200 bp) 16S rRNA gene sequences from these and similar sites. Heatmaps showing the relative abundance of phylotypes were generated in $\mathrm{R}$ with the heatmap.plus package. Bray-Curtis dissimilarities were calculated with the vegan community ecology package in $\mathrm{R}$ (Oksanen et al., 2016). The abundance of phylotypes from mature Fe(III)-oxide mats were compared using Illumina 16S rRNA gene barcodes vs. Illumina random metagenome sequencing from matching samples. Barcoded 16S rRNA gene amplification using universal archaeal and bacterial primers (515F/806R; Caporaso et al., 2010; Earth Microbiome Project, http://www. earthmicrobiome.org/) on mature Fe(III)-oxide mats resulted in overestimation of Hydrogenobaculum spp. and underestimation of M. yellowstonensis-like organisms (see Table 2 in Results). The under- and overestimation of these phylotypes is caused by a mismatch of the $515 \mathrm{~F}$ primer to the $16 \mathrm{~S}$ rRNA gene in M. yellowstonensis (phylum Crenarchaeota), and is an important consideration for universal primer-based studies of $\mathrm{Fe}(\mathrm{III})$-oxide microbial mats that contain abundant members of the Crenarchaeota. Although the relative abundance of Hydrogenobaculum spp. was corrected for two copies of the $16 \mathrm{~S}$ rRNA gene, this adds more sequences to the PCR pool, and could result in additional overestimation. The 16S rRNA gene PCR amplification step using universal primers on these relatively simple communities illustrates how a single primer mismatch to the target sequence can cause a large discrepancy in relative abundance estimates of an important community member (i.e., M. yellowstonensis). Metagenome data for One Hundred Spring Plain (OSP_B) is located under the Integrated Microbial Genome Submission IDs 10386 (Illumina) and 1781 (454), and Beowulf Spring (BE_D) 10390 (Illumina), 2254 (454), and 278 (Sanger).

\section{Oxygen Microsensor Measurements}

Oxygen microsensor measurements were made on May 21, 2013 at OSP Spring Fe(III)-oxide microbial mats (temperature = $\left.75^{\circ} \mathrm{C}, \mathrm{pH}=3.5, \mathrm{O}_{2}(\mathrm{aq})=55 \mu \mathrm{M}\right)$ to identify variation in net areal $\mathrm{O}_{2}$ fluxes compared to prior measurements at OSP and Beowulf Spring Fe(III)-oxide mats (Bernstein et al., 2013). Custom Clark-type oxygen electrodes (tip diameter $=$ $50 \mu \mathrm{m})$ designed with a high-temperature resistant electrolyte solution (Unisense A/S, Aarhus, Denmark) were used to make replicate measurements at OSP Spring $\left(\mathrm{O}_{2}\right.$ microelectrode measurements were not repeated at Beowulf Spring Fe(III)-oxide mats due to difficulties (i.e., breaking microsensors) making these measurements on the harder Fe(III)-oxide mats present in this spring. Details on flux and reaction-diffusion modeling were discussed in Bernstein et al. (2013). Briefly, $\mathrm{O}_{2}$ microprofiles $(n=11)$ were modeled (first-order) using the dimensionless equation, $\mathrm{u}=\left(\varphi^{2} \bullet \zeta^{2}\right) / 2-\varphi^{2} \bullet \zeta+1$, where $\mathrm{u}=\mathrm{C}_{\mathrm{O}_{2}} / \mathrm{C}_{\mathrm{O}_{2}}$, $\zeta=\mathrm{z} / \mathrm{L}_{\mathrm{f}}$, and $\varphi^{2}=\mathrm{k}_{1} \mathrm{~L}_{\mathrm{f}}^{2} / \mathrm{D}_{\mathrm{e}}\left(\mathrm{z}=\right.$ mat depth, $\mathrm{C}_{\mathrm{O}_{2}}=$ oxygen concentration, $\mathrm{C}_{\mathrm{O}_{2}}$ ' $=$ bulk $\mathrm{O}_{2}$ concentration, $\mathrm{k}_{1}=$ first-order rate constant, $\mathrm{L}_{\mathrm{f}}=$ mat thickness, and $\mathrm{D}_{\mathrm{e}}=$ diffusion coefficient of $\mathrm{O}_{2}$ ). The solution of this equation provides an estimate of the relative contribution of the rate of $\mathrm{O}_{2}$ diffusion vs. the rate of $\mathrm{O}_{2}$ consumption ( $\varphi=$ Thiele Modulus), where $\varphi>0$ indicates that diffusion is limiting and $\varphi<0$ indicates that the reaction rate is limiting the observed rate of consumption (Thiele, 1939).

\section{RESULTS}

\section{Early Colonization}

Rod-shaped bacteria colonized slides rapidly, and significant cell densities of these organisms were observed using scanning electron microscopy (SEM) within 4-7 days of incubation in both OSP and Beowulf Springs (Figure 2). The taxonomic identity of these bacteria was confirmed to be Hydrogenobaculum spp. using 16S rRNA gene specific fluorescence in situ hybridization (FISH) probes (Figure 3). After confident taxonomic assignment of these bacteria, SEM images were useful for obtaining growth estimates during early incubation times ( $<14$ days), prior to the extensive deposition of Fe-oxides and exogenous debris that precluded accurate cell counting. Colonization rate estimates of Hydrogenobaculum spp. were $3.7 \pm 1.8 \bullet 10^{6}$ and $6.8 \pm 3.4 \bullet$ $10^{6}$ cells $\mathrm{cm}^{-2}$ day $^{-1}$ in OSP and Beowulf Springs, respectively. Coccus-shaped archaea were also identified at early time points (e.g., within 4-7 days) using both SEM and FISH (Figure 3), but were considerably less abundant than Hydrogenobaculum spp. (Figures 2, 3). Although M. yellowstonensis probes have proven difficult in Fe(III)-oxide samples in situ (Kozubal et al., 2008), archaeal probes were positive and molecular data (below) indicated that early-colonizing archaea were M. yellowstonensislike organisms. Early-colonizing archaea were often found as individuals within 4-6 days, and as microcolonies containing up to 50 cells within 15 days (Figures $2 \mathbf{C}-\mathbf{E}$ ). These cocci colonized at rates of approximately $9.2 \pm 5.1 \bullet 10^{5}$ and $8.6 \pm 4.1 \bullet 10^{5}$ cells $\mathrm{cm}^{-2}$ day $^{-1}$ in OSP and Beowulf Springs, respectively, which is nearly five times slower than the colonization rates by Hydrogenobaculum spp. Visible Fe-oxide staining from 7 to 14 days also corresponded to the detection and proliferation of these archaea. Hydrogenobaculum spp. and M. yellowstonensis were 


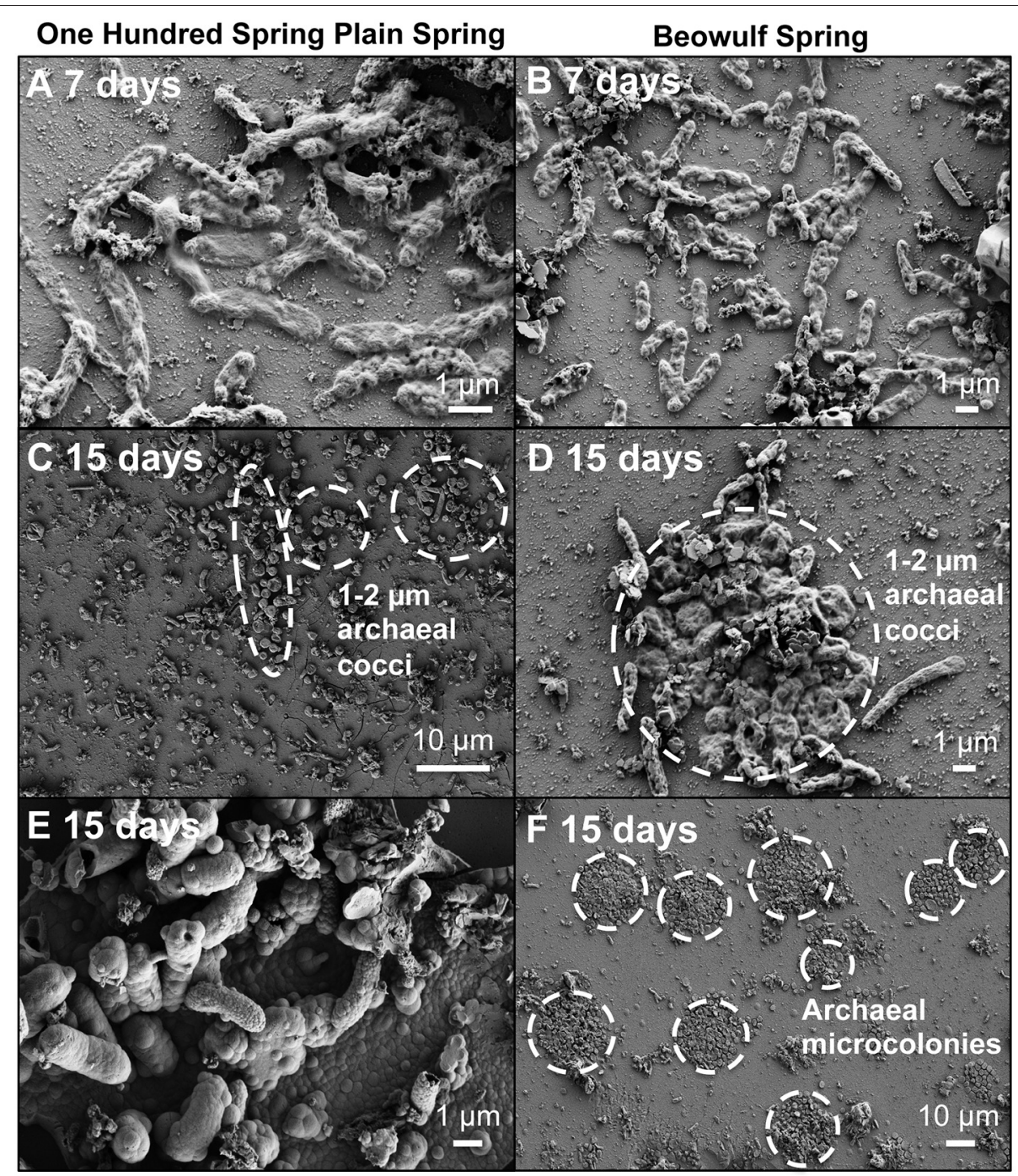

FIGURE 2 | Scanning electron micrographs of slides incubated for 7 and 15 days in Fe(III)-oxide mats from One Hundred Spring Plain (A,C,E from 7/13/2011 and 7/21/2013) and Beowulf Spring (B,D,F from 7/13/2011 and 7/21/2011). Archaeal microcolonies from Beowulf Spring (F) are highlighted with dashed circles.

often observed in close spatial proximity (Figure 2D), which suggests that these populations are interacting in situ.

\section{Iron Oxide Accretion}

The biomineralization of poorly-crystalline Fe(III)-oxide phases occurred as visible crusts on Hydrogenobaculum rods and filaments at times $>7$ days (Figure 2). These arsenate-rich, poorly-crystalline $\mathrm{Fe}(\mathrm{III})$-oxide phases (Inskeep et al., 2004) begin to dominate the available surface area and form larger $(>1 \mu \mathrm{m})$ crusts on outer cell surfaces of Hydrogenobaculum spp. and other inorganic templates (e.g., $\mathrm{SiO}_{2}$ and alunite) at incubation times greater than 14 days (Figure 2E). Direct observations of temporal changes in Fe(III)-oxide deposition using SEM were corroborated with data obtained on Fe(III)oxide accretion as a function of time.

Iron oxide deposition increased exponentially with time (days) in both OSP and Beowulf Springs (Figures 4A,B), and was modeled using a first-order rate equation $\left(\mathrm{Fe}_{\mathrm{x}}=\mathrm{Fe}_{\mathrm{o}} \mathrm{e}^{\mathrm{kt}}\right)$ where $\mathrm{Fe}_{\mathrm{x}}$ is $\mathrm{Fe}$ (III)-oxide accreted ( $\mu \mathrm{mol} \mathrm{Fe} \mathrm{cm}^{-2}$ ), $\mathrm{Fe}_{\mathrm{o}}$ is the initial $\mathrm{Fe}$ (III)-oxide concentration $\left(\mu \mathrm{mol} \mathrm{Fe} \mathrm{cm}^{-2}\right.$ ), and $\mathrm{k}$ is the empirical first-order rate constant $\left(\mathrm{day}^{-1}\right)$. A lag phase of Fe(III)oxide accretion occurred from 0 to $\sim 30$ days (Figures 4 A,B), which corresponded to the slower growth rate of $\mathrm{Fe}(\mathrm{II})$-oxidizing microorganisms. The fitted first-order rate constants for Fe(III)oxide accretion were 0.05 day $^{-1}$ (std. error $=0.003, p=2.5 \bullet$ $10^{-15}$ ) and $0.047 \mathrm{day}^{-1}\left(\mathrm{std}\right.$. error $=0.005, p=2.98 \bullet 10^{-10}$ ) at OSP and Beowulf, respectively. Similar rate constants (within $10 \%)$ describing the accumulation of Fe-oxides were observed for OSP and Beowulf springs across multiple field seasons and suggest that similar processes control the deposition of $\mathrm{Fe}(\mathrm{III})$ oxides in these habitats. The lower amount of Fe(III)-oxide accreted by 70 days of incubation in Beowulf Spring relative to OSP was significant ( $p=0.0018$, student's two-tailed T-test) and may be attributed to differences in spring geochemistry (e.g., 
lower $\mathrm{pH}$ and temperature) and local hydrodynamic conditions. Specifically, the higher flow velocities and higher Reynolds numbers in Beowulf vs. OSP Spring $\left(R=1.4 \bullet 10^{4}\right.$ and $1.5 \bullet$

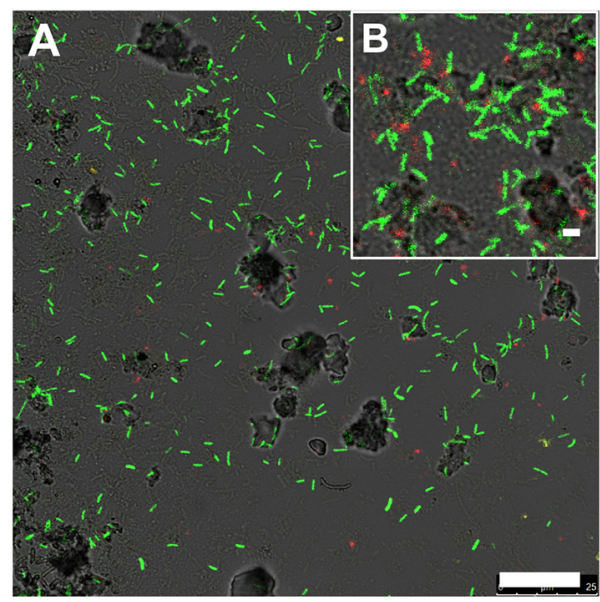

FIGURE 3 | Fluorescence in situ hybridization image of slides incubated in Beowulf Spring for 6 days $(A, B)$. Green rods are Hydrogenobaculum spp. (6FAM-Aqi338) and red cocci are archaea (Cy5-Arch915). Scale bar $=20 \mu \mathrm{m}$ (A) and $1 \mu \mathrm{m}$ (B).
$10^{3}$, respectively) resulted in lower amounts of Fe deposition

(Table 1). The vertical growth of $\mathrm{Fe}(\mathrm{III})$-oxide mats in acidic geothermal springs occurred at a rate of $\sim 15-30 \mu \mathrm{m}$ day $^{-1}$ $\left(0.5-1 \mathrm{~mm} \mathrm{month}^{-1}\right)$, although the maximum vertical growth is ultimately limited by channel water depths. Maximum rates of $\mathrm{Fe}$ (III)-oxide accretion in acidic geothermal springs $(\sim 0.9 \mu \mathrm{mol}$ $\mathrm{Fe} \mathrm{cm}^{-2} \mathrm{day}^{-1}$ ) fall within the range observed for other systems (0.09-9 $\mu \mathrm{mol} \mathrm{Fe} \mathrm{cm}^{-2} \mathrm{day}^{-1}$ ), which includes estimates of $\mathrm{Fe}$ deposition rates in banded iron formations (Konhauser, 1998) as well as observations in circumneutral $\mathrm{pH}$ environments (Hanert, 1974; Emerson and Revsbech, 1994).

\section{Temporal Changes in Microbial Community Composition}

The amount of microbial biomass (expressed as ng DNA $\mathrm{cm}^{-2}$ ) increased as a function of time in OSP and Beowulf Springs, and also followed a first-order rate equation (Figures 4C,D), similar to $\mathrm{Fe}$ (III)-oxide accretion. A lag phase in the accumulation of total community DNA was also observed up to $\sim 30$ days, after which DNA increased exponentially. The fitted rate constants for DNA accumulation were $0.028 \mathrm{day}^{-1}$ (std. error $=0.0063, p=0.0062$ ) and $0.043 \mathrm{day}^{-1}$ (std. error $=0.0087 ; p=0.0026$ ) for OSP and Beowulf Springs, respectively. These values are essentially similar to the fitted

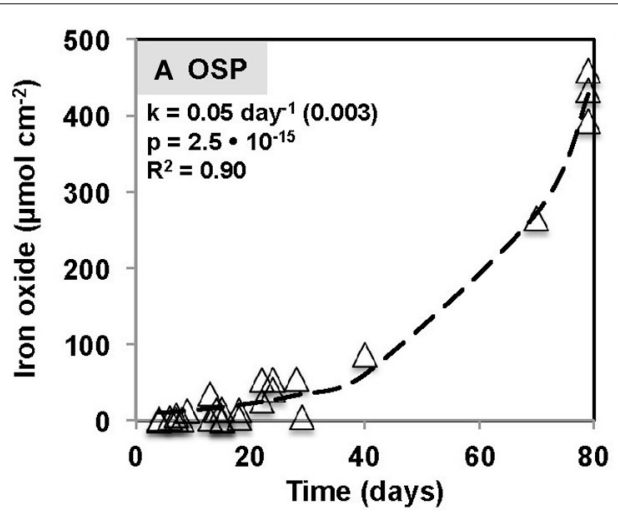

100
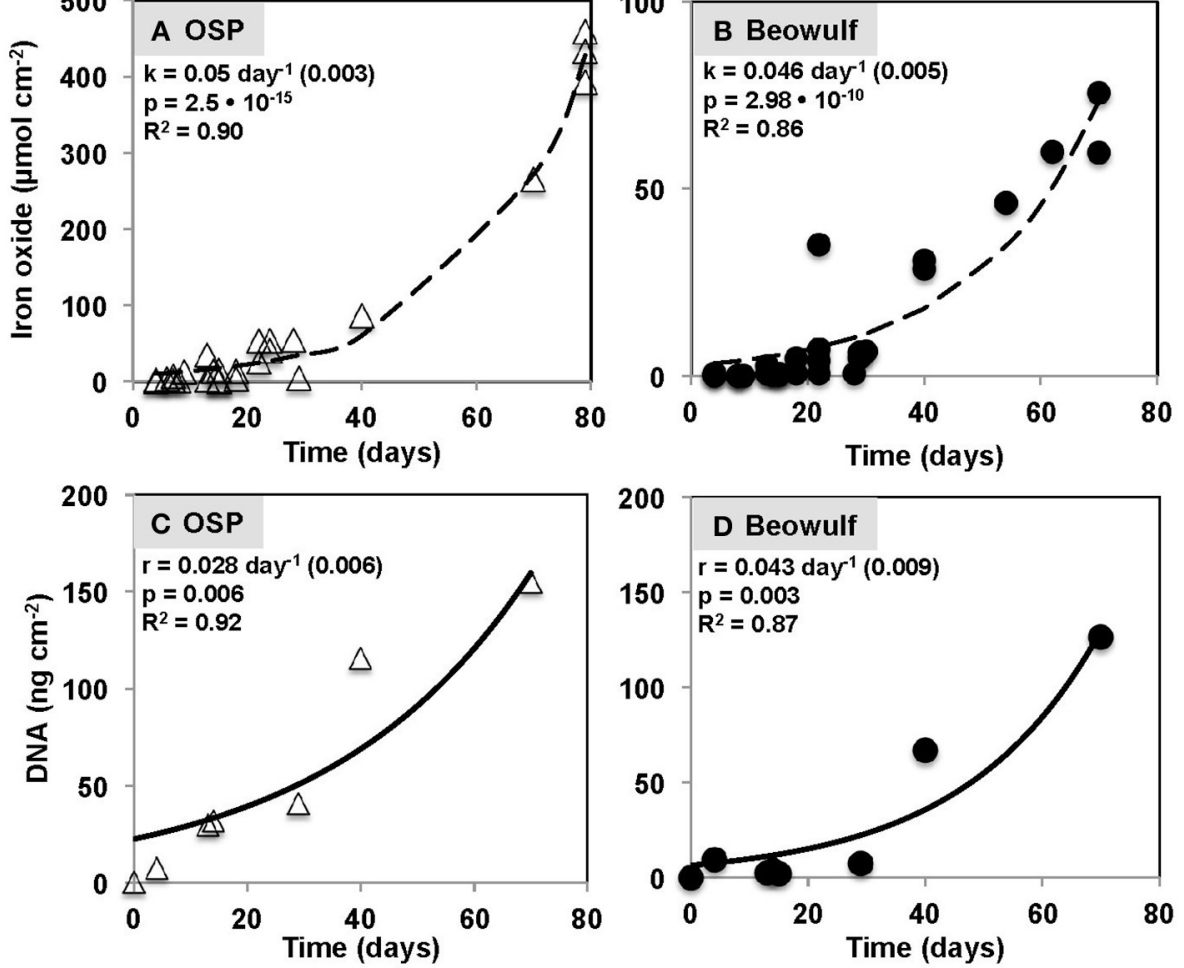

FIGURE 4 | Iron oxide accretion measured on glass slides incubated as a function of time in One Hundred Spring Plain (OSP) (A) and Beowulf (B) Springs outflow channels in Norris Geyser Basin, Yellowstone National Park. The dashed black line represents a model fit to the exponential rate expression

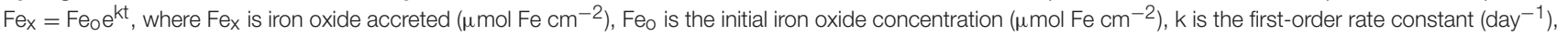
and $t$ is time (day). Total DNA concentrations determined from slides incubated in One Hundred Spring Plain (OSP) (C) and Beowulf Spring (D) over a time period of 70 days. The solid black line represents a model fit to the exponential rate expression $D N A_{x}=D N A_{\circ} e^{r t}$, where DNAx is DNA accumulated (ng DNA cm ${ }^{-2}$ ), DNA。 is the initial DNA concentration ( $\mathrm{ng}$ DNA cm${ }^{-2}$ ), $\mathrm{r}$ is the first-order rate constant (day ${ }^{-1}$ ), and $\mathrm{t}$ is time (day). 
rate constants for $\mathrm{Fe}$ accretion, and it is clear from the time series behavior that Fe accumulation and DNA accumulation are also correlated (Figure 4). Molecular data confirmed that the lithoautotrophic populations of Hydrogenobaculum spp. and Metallosphaera yellowstonensis were the dominant community members ( $>90 \%)$ at early stages of mat development ( $<30$ days) (Figure 5). The abundance of $M$. yellowstonensis was relatively constant (10-20\%) throughout mat development. In contrast, Hydrogenobaculum spp. abundance was highest during early stages of colonization, and declined after 15-30 days (Figure 5) as mat depth increased and other heterotrophic archaea contributed to the total mat community.

Dendrograms of microbial community structure as a function of time were compared to population abundances of mature
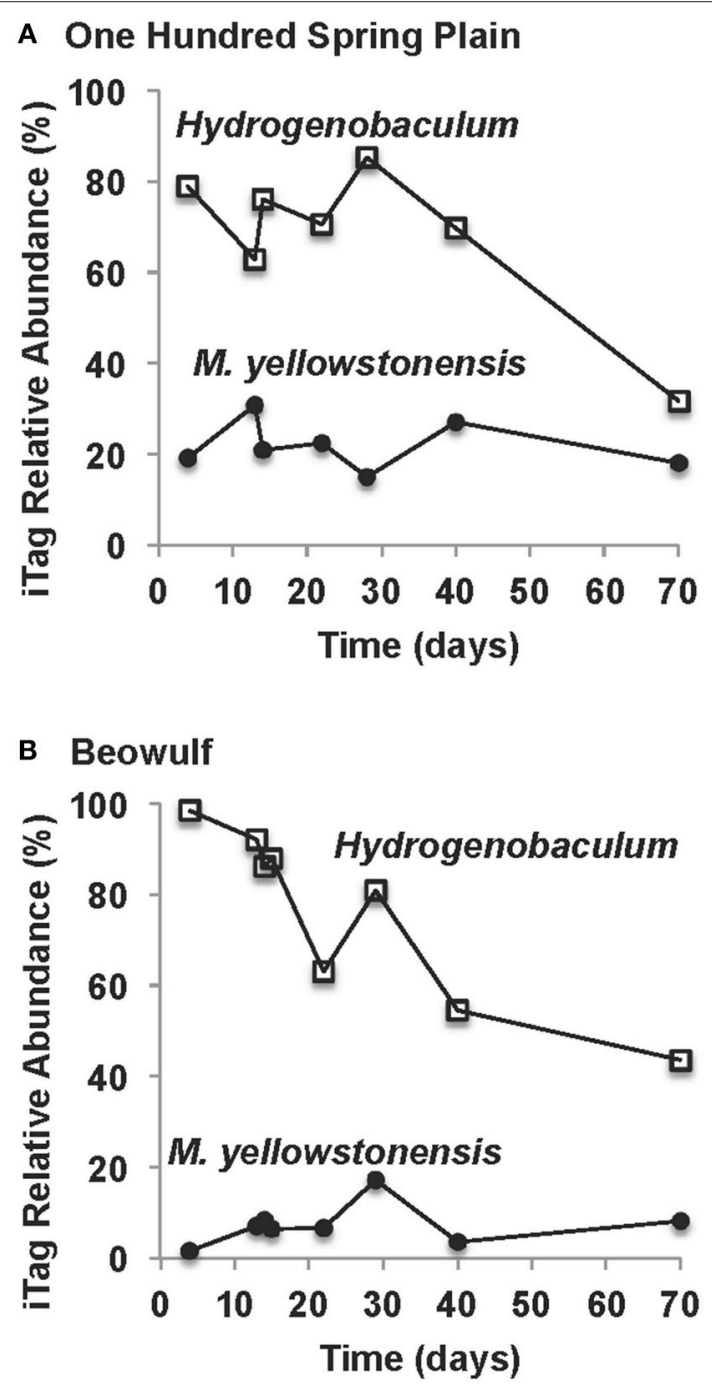

FIGURE 5 | Relative abundance (16S rRNA gene iTags) of key lithoautotrophic microbial populations over the time course of slide incubations in One Hundred Spring Plain (A) and Beowulf (B) Springs (Hydrogenobaculum spp. = open squares; Metallosphaera yellowstonensis $=$ closed black circles).
Fe(III)-oxide mats (Figure 6). The population abundances of $\mathrm{Fe}(\mathrm{III})$-oxide mat communities from early incubation times ( $<40$ days) were more similar to one another compared to later time points ( $>70$ days), which reflects progression toward "mature" 0.5-2 cm thick Fe(III)-oxide mats (Table 2, Figure 6). The dominant microbial population observed from 4 to 70 days was Hydrogenobaculum spp., which was consistent with direct observations using SEM and FISH. Although Hydrogenobaculum spp. were especially dominant at times $<14$ days (Figure 6), their abundance declined on average of $\sim 1 \%$ per day with increasing mat depths. Using this estimate, relative abundances of Hydrogenobaculum spp. would reach $\sim 1-3 \%$ after 100 days, which is within the range observed for "mature" Fe(III)oxide mats of $0.5-2 \mathrm{~cm}$ thickness (Table 2). Metallosphaera yellowstonensis was the only other population detected in significant numbers at early time points and remained relatively constant over the time series, representing $\sim 10-20 \%$ of the total microbial community (Figure 6). Iron-oxide accretion increased

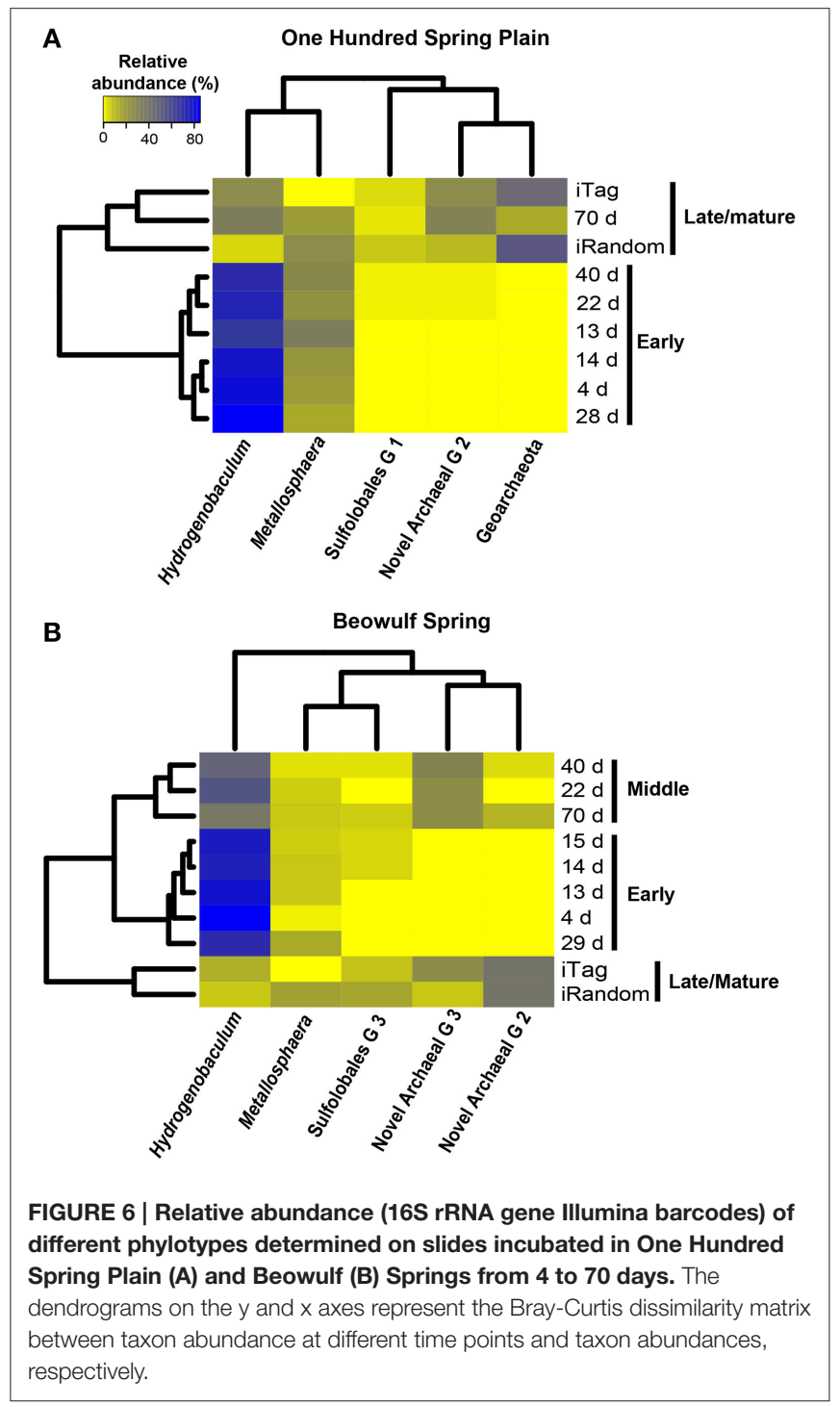


significantly after 40 days and this corresponded to the detection of several heterotrophic archaea, which represented the majority of the total community (in aggregate) by 70 days (Table 2 , Figure 6), as well as in "mature" Fe-oxide mats (reaching depths of $0.5-2 \mathrm{~cm}$ ).

Although the predominant lithoautotrophs responsible for $\mathrm{Fe}$ (III)-oxide mat formation are the same in the two geothermal springs studied, different heterotrophic assemblages between sites were also evident. For example, populations of a novel archaeal Group 3 (NAG3), which are phylogenetically related to the archaeal order Thermoplasmatales (Inskeep et al., 2010; Kozubal et al., 2012), were especially important in Beowulf Spring at later time points (Figure 6). Furthermore, members of Sulfolobales Group 3, which includes a novel heterotrophic $\mathrm{Fe}(\mathrm{II})$-oxidizing species (Kozubal et al., 2012), appeared later in community succession ( $\sim 20$ days) at Beowulf Spring, and may contribute to $\mathrm{Fe}$ (III)-oxide accretion in this site. Several other heterotrophic archaea were observed in mid to later stages of $\mathrm{Fe}(\mathrm{III})$-oxide mat succession, and although these phylotypes were present in lower abundance $(<1-2 \%)$, all have been observed in acidic Fe(III)-oxide mats from YNP (Kozubal et al., 2012), and these chemoorganotrophs do not have genes required for the fixation of $\mathrm{CO}_{2}$ (Jennings et al., in review), which suggests that they rely (in part) on organic C produced by Hydrogenobaculum spp. and M. yellowstonensis.

The relative abundance of different phylotypes in "mature" (0.5-2 cm thick) Fe(III)-oxide microbial mats was estimated from random shotgun metagenome and $16 \mathrm{~S}$ rRNA gene sequencing (Table 2, Figure 6). Metallosphaera yellowstonensis populations ranged from $\sim 4$ to $16 \%$ of the microbial community across temperatures of $65-75^{\circ} \mathrm{C}$ (Table 2), and is consistent with the reported optimum growth temperature (Kozubal et al., 2008). Other Sulfolobales populations were also detected, and a representative of Sulfolobales Group 3 (strain MK5) has been shown to oxidize Fe(II) heterotrophically (Kozubal et al., 2012). Hydrogenobaculum spp. were less abundant in mature Fe(III)-oxide mats (Table 2), which is consistent with the measured decline in these populations over time (Figures 5, 6). Members of the Geoarchaeota (Kozubal et al., 2013) represent the dominant heterotrophic phylotype in OSP Spring, whereas members of a novel archaeal Group 2 (NAG2; Kozubal et al., 2012) were the dominant heterotrophs in Beowulf Spring. Deeply-branching Thaumarchaeota (Beam et al., 2014) were also observed in mature Fe mats, and were abundant in Beowulf Spring (Table 2). Differences in temperature and $\mathrm{pH}$ between the two sites likely influence the relative abundance(s) of these heterotrophic archaeal populations (Kozubal et al., 2012).

\section{In situ Oxygen Consumption and Formation of Microterracettes}

Oxygen microelectrode measurements in OSP Spring Fe(III)oxide mats revealed an areal $\mathrm{O}_{2}(\mathrm{aq})$ consumption rate of $1.14 \cdot 10^{-4} \mu \mathrm{mol} \mathrm{cm}{ }^{-2} \mathrm{~s}^{-1}$ (Figure 7). The concentration of $\mathrm{O}_{2}$ (aq) ranged from $\sim 55 \mu \mathrm{M}$ at the mat-aqueous interface and dropped to below detection $(<0.3 \mu \mathrm{M})$ within the top $1 \mathrm{~mm}$. These observations are consistent with prior $\mathrm{O}_{2}$ microelectrode measurements in the same Fe(III)-oxide mat systems (Table 3). Dimensionless reaction-diffusion model fits (see Materials and Methods) of oxygen microprofiles resulted in an estimate of 28 for the Thiele modulus $(\varphi)$, which indicates that the rate of biotic $\mathrm{O}_{2}$ consumption was at least an order of magnitude faster than $\mathrm{O}_{2}$ diffusion into the $\mathrm{Fe}(\mathrm{III})$-oxide mats (Bernstein et al., 2013). Thus, the microbial consumption of $\mathrm{O}_{2}$ is limited by the rate of $\mathrm{O}_{2}$ diffusion; an average flux of $\mathrm{O}_{2}$ into these poorly-crystalline Fe(III)-oxide mats was $1.2 \pm 0.5 \bullet 10^{-4} \mu \mathrm{mol} \mathrm{cm} \mathrm{cm}^{-2} \mathrm{~s}^{-1}$ at temperatures ranging from 60 to $75^{\circ} \mathrm{C}$ (Table 3 ).

TABLE 2 | The relative abundance of different phylotypes from "mature" Fe(III)-oxide mats of One Hundred Spring Plain and Beowulf Spring (YNP) determined using random DNA sequencing over multiple years (and sequencing technologies), or short-fragment 16S rRNA gene sequencing (Illumina iTag).

\begin{tabular}{|c|c|c|c|c|c|c|c|}
\hline \multirow[t]{2}{*}{ Spring } & \multicolumn{3}{|c|}{ One Hundred Spring Plain Spring } & \multicolumn{4}{|c|}{ Beowulf Spring } \\
\hline & Random & Random & 16S Tags & Random & Random & Random & 16S Tags \\
\hline Sequencing technology & 454 & Illumina & Illumina & Sanger & 454 & Illumina & Illumina \\
\hline $\mathrm{pH} /$ Temperature $\left({ }^{\circ} \mathrm{C}\right)$ & $3.6 / 72$ & $3.5 / 75$ & $3.5 / 75$ & $3 / 65$ & 2.9/66 & 2.9/68 & 2.9/68 \\
\hline
\end{tabular}

\section{PHYLOTYPE}

RELATIVE ABUNDANCE (\%)

\begin{tabular}{|c|c|c|c|c|c|c|c|}
\hline M. yellowstonensis & 10.3 & 16 & 0.51 & 3.9 & 6.6 & 12 & - \\
\hline Hydrogenobaculum spp. & 3.4 & 3 & 24.2 & 2 & 1.2 & 4.3 & 14 \\
\hline Geoarchaeota & 43.4 & 33 & 41 & 1 & 3 & 6 & 4 \\
\hline Novel archaeal group 2 & 4 & 6 & 24 & 26 & 38 & 27 & 42 \\
\hline Thaumarchaeota & 0.4 & 0.4 & 3 & 19 & 4.4 & 2 & 3.2 \\
\hline Novel archaeal group 3 & 0.1 & 0.12 & - & 4 & 3 & 5 & 26 \\
\hline Other Sulfolobales & 2.5 & 4 & 3.3 & 3.9 & 10 & 11 & 8.5 \\
\hline Nanoarchaeota & 0.2 & 0.6 & - & 0 & 0.1 & 0.6 & - \\
\hline
\end{tabular}

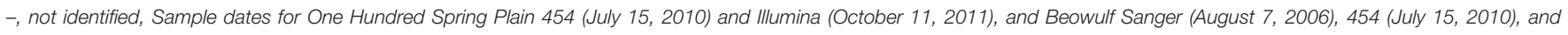
Illumina (November 16, 2011). 
Microterracettes containing both Hydrogenobaculum spp. and M. yellowstonensis were observed within 6 days, already reaching heights up to $10 \mu \mathrm{m}$ and spaced at $\sim 10-20 \mu \mathrm{m}$ intervals (Figure 8). These smaller microterracettes may coalesce to form larger $(\sim 1 \mathrm{~mm}$ high) structures (Figure 8), which evolve into visible $\mathrm{cm}$-scale microterracettes common in mature $\mathrm{Fe}$ (III)oxide mats (Figure 1). These structures increase the overall surface area and flux of $\mathrm{O}_{2}$ into the mat system, similar to the formation of "wrinkles" in microbial communities, which have been shown to form as a result of $\mathrm{O}_{2}$ mass transfer limitations to microorganisms (Okegbe et al., 2014). The relative size and periodicity of microterracettes is likely correlated with the extent and size of the mass transfer boundary layer, which is a function of water velocity and character (i.e., turbulent vs. laminar flow), as well as physical properties of the biomineralized mat.

\section{Vertical Stratification of Microbial Populations}

Oxygen gradients result in the stratification of $\mathrm{Fe}(\mathrm{III})$-oxide mat community members. We dissected "mature" Fe(III)-oxide mats into discrete zones (top $1 \mathrm{~mm}$, middle, bottom) for $16 \mathrm{~S}$ rRNA gene (iTag) analysis, which revealed stratification of the microbial community as a function of mat depth (Figure 9).

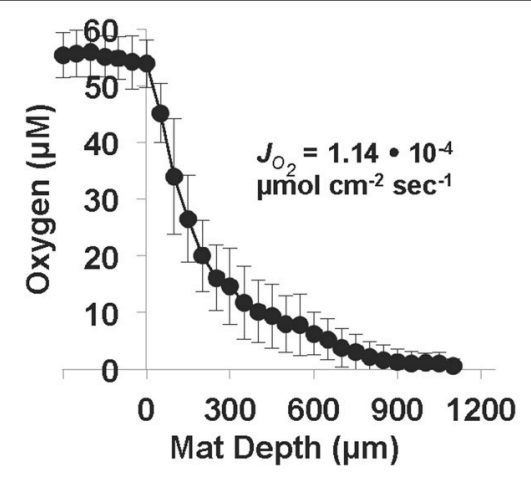

FIGURE 7 | Oxygen microprofiles $(n=11$, electrode tip diameter $=50$ $\mu \mathrm{m}$ ) measured in One Hundred Spring Plain Fe(III)-oxide mats (May 2013; temperature $=75^{\circ} \mathrm{C}, \mathrm{pH}=3.5, \mathrm{O}_{2}(\mathrm{aq}) \sim 55 \mu \mathrm{M}$ ). The diffusive flux of oxygen, $J_{\mathrm{O}_{2}}$, was estimated from the measured concentration profiles as a function of $\mathrm{Fe}(\mathrm{III})$-oxide mat depth. Position zero refers to the aqueous-Fe(III)-oxide mat interface.
Specifically, M. yellowstonensis and Hydrogenobaculum spp. were more abundant in the top $1 \mathrm{~mm}$ of the Fe(III)-oxide surface relative to middle or bottom positions, which is consistent with the high $\mathrm{O}_{2}$ requirements of these lithoautotrophs. Microaerobic chemoorganotrophs (i.e., NAG2 and Geoarchaeota) were more abundant in middle and bottom mat sections (Kozubal et al., 2012). The relative abundance of hypoxic community members such as Acidilobus spp. (order Desulfurococcales) increased in bottom mat positions, which is consistent with the metabolic attributes of these organisms (Jay et al., 2014) and the low $\mathrm{O}_{2}$ concentrations $(<0.3 \mu \mathrm{M})$ observed at mat depths $>1 \mathrm{~mm}$ (e.g., Table 3, Figure 8). These data are also consistent with prior results showing that active $\mathrm{Fe}(\mathrm{II})$-oxidizing M. yellowstonensis populations are higher in the upper $(\sim 1 \mathrm{~mm})$ mat layer (Bernstein et al., 2013).

\section{Adsorption of Oxyanions}

The biomineralization of Fe(III)-oxides in acidic mats of NGB results in the concomitant adsorption, coprecipitation and/or biomass uptake of oxyanions such as arsenate, phosphate and tungstate over time (Figure 10) (e.g., Leblanc et al., 1996; Karl et al., 1988). Molar ratios of As:Fe over all time points ranged from 0.5 (OSP) to 0.67 (Beowulf), which is consistent with prior measurements of As:Fe ratios in "mature" Fe(III)-oxide mats (Langner et al., 2001; Inskeep et al., 2004; Macur et al., 2004). The co-accumulation of As, P, W and Fe could provide evidence of microbiological activity under acidic conditions [e.g., $\mathrm{Fe}(\mathrm{II})$ and $\mathrm{As}(\mathrm{III})$ oxidation and subsequent biomineralization]. Molar ratios of $\mathrm{P}(0.01)$ and $\mathrm{W}(0.002)$ to $\mathrm{Fe}$ were similar between OSP and Beowulf Springs (Figure 10). Tungsten may substitute for molybdenum in enzymes (e.g., dimethyl sulfoxide molybdopterins) utilized by thermoacidophilic organisms to perform specific functions such as arsenite oxidation or degradation of organic matter (Kletzin and Adams, 1996).

\section{DISCUSSION}

A conceptual model describing the assembly and succession of thermoacidic Fe(III)-oxide microbial mats was developed by integrating geochemical, imaging, and molecular measurements across multiple scales of observation. The life cycle of a high-temperature $\mathrm{Fe}$ (III)-oxide mat in the acid-sulfate-chloride springs of Norris Geyser Basin (YNP) can be represented by four stages (Figure 11). Early colonization (Stage I) by aerobic,

TABLE 3 | Oxygen flux estimates, penetration depths, and Thiele ${ }^{a}$ moduli describing oxygen diffusion in thermoacidic Fe(III)-oxide mats from Norris Geyser Basin, Yellowstone National Park.

\begin{tabular}{|c|c|c|c|c|c|}
\hline Spring/Temperature $\left({ }^{\circ} \mathrm{C}\right)$ & Sample date & Net areal $O_{2}$ flux $\left(\mu \mathrm{mol} \mathrm{cm} \mathrm{cm}^{-2} \mathrm{~s}^{-1}\right)$ & Penetration depth $(\mu \mathrm{m})$ & Thiele modulus & References \\
\hline One Hundred Spring Plain/75 & May 21, 2013 & $1.14 \cdot 10^{-4}$ & 950 & 28 & This study \\
\hline One Hundred Spring Plain/75 & August 18, 2010 & $1.41 \cdot 10^{-4}$ & 750 & 30 & Bernstein et al., 2013 \\
\hline Beowulf/68 & July 6, 2011 & $1.64 \cdot 10^{-4}$ & $250-1000$ & 60 & Bernstein et al., 2013 \\
\hline Beowulf/60 & July 13, 2004 & $5 \cdot 10^{-5}$ & 500 & nd & $\begin{array}{l}\text { Kühl and Kozubal, } \\
\text { unpublished }\end{array}$ \\
\hline
\end{tabular}

a see Methods for definition of Thiele modulus. 


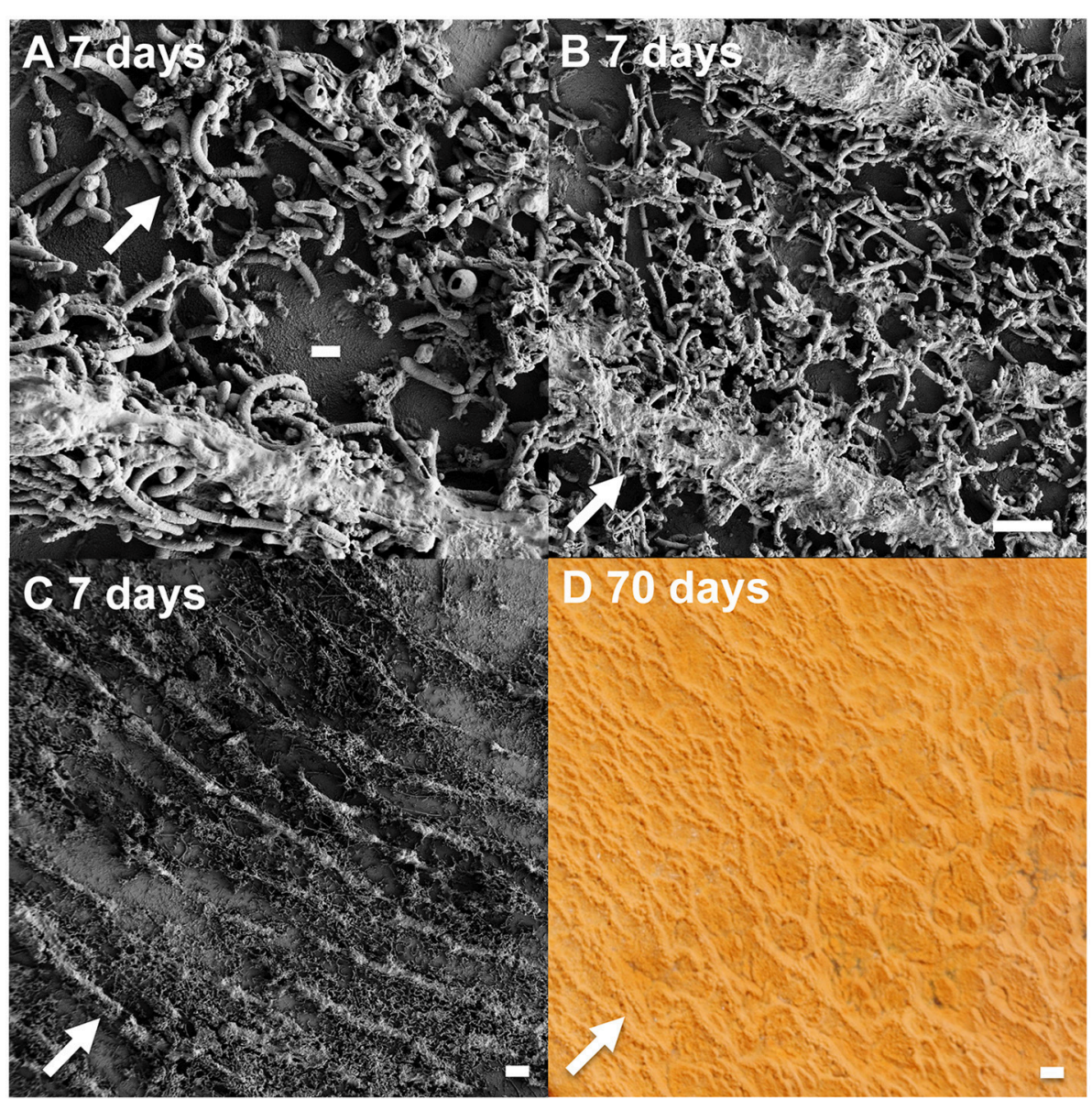

FIGURE 8 | Growth and formation of microterracettes from slides incubated in Beowulf Spring. Scanning electron micrographs (A-C) of ridge structures: scale bar $=1 \mu \mathrm{m}$ (A), and $10 \mu \mathrm{m}$ (B,C). Photograph of larger, $1 \mathrm{~mm}$ ridges (D) present in 70 days Fe(III)-oxide mats incubated for 70 days (scale bar $=1 \mathrm{~mm}$ ). The flow direction (arrows) is perpendicular to microterracettes.

chemolithoautotrophic populations of Hydrogenobaculum spp. and Metallosphaera yellowstonensis provides critical founder populations for initial surface roughness and continued mat growth. Hydrogenobaculum spp. exhibit significantly greater colonization rates than M. yellowstonensis (factor of 5) in hightemperature acidic Fe(III)-oxide mats. The aerobic oxidation of arsenite (and/or reduced sulfur species) by Hydrogenobaculum spp. (D'Imperio et al., 2007, 2008; Hamamura et al., 2009) and $\mathrm{Fe}(\mathrm{II})$ by M. yellowstonensis (Kozubal et al., 2008) is coupled with the fixation of DIC as a primary $\mathrm{C}$ source via the reductive tricarboxylic acid and 3-hydroxypropionate/4-hydroxybutyrate cycles, respectively (Berg et al., 2007; Takacs-Vesbach et al., 2013; Jennings et al., 2014), and provides the Fe(III) and As(V) necessary for the formation of high-As, poorly-crystalline Fe(III)oxides characteristic of these springs (Langner et al., 2001; Inskeep et al., 2004; Macur et al., 2004).

Appreciable amounts of $\mathrm{Fe}(\mathrm{III})$-oxides are produced between $\sim 7$ and 30 days (Stage II), which correlates with the establishment of M. yellowstonensis (e.g., microcolonies of 10-50 cells), and which results in the encrustation of rapidly-growing Hydrogenobaculum rods and filaments (Figure 2). The cell surface of Hydrogenobaculum may contain macromolecules that aid in the nucleation of poorly-crystalline Fe(III)-oxide phases, because these cells are encrusted preferentially (also see Macur et al., 2004). Moreover, Fe(III)-oxides do not accumulate on the cell surface(s) of $M$. yellowstonensis under culture conditions (Kozubal et al., 2008), or in situ (Figure 2). Hydrogenobaculum spp. inhabit a large reach (several meters) within the outflow channels of OSP and Beowulf Springs (Figures 1A,B), and data obtained during the first 4 days of slide placement suggest that these organisms are continually colonizing the upper surface of iron mats where $\mathrm{O}_{2}$ concentrations are highest. Higher rates of cell growth occur along microscale ridges as early as 6-7 days (Figure 8). These structures reflect the microbial control of microterracette formation in acidic $\mathrm{Fe}$ (III)-oxide mats, and are likely formed in response to $\mathrm{O}_{2}$ mass transfer limitations (Figure 7) to growing chemolithotrophic populations (i.e., Hydrogenobaculum and M. yellowstonensis). Cell growth proceeds upward into the shallow, high-velocity $(\sim 20-30 \mathrm{~cm}$ $\mathrm{s}^{-1}$ ) aqueous phase where $\mathrm{O}_{2}(\mathrm{aq})$ concentrations range from 20 to $60 \mu \mathrm{M}$ (Table 1), and results in Fe(III)-oxide mat heights of $0.5-1 \mathrm{~mm}$ within 30 days. 

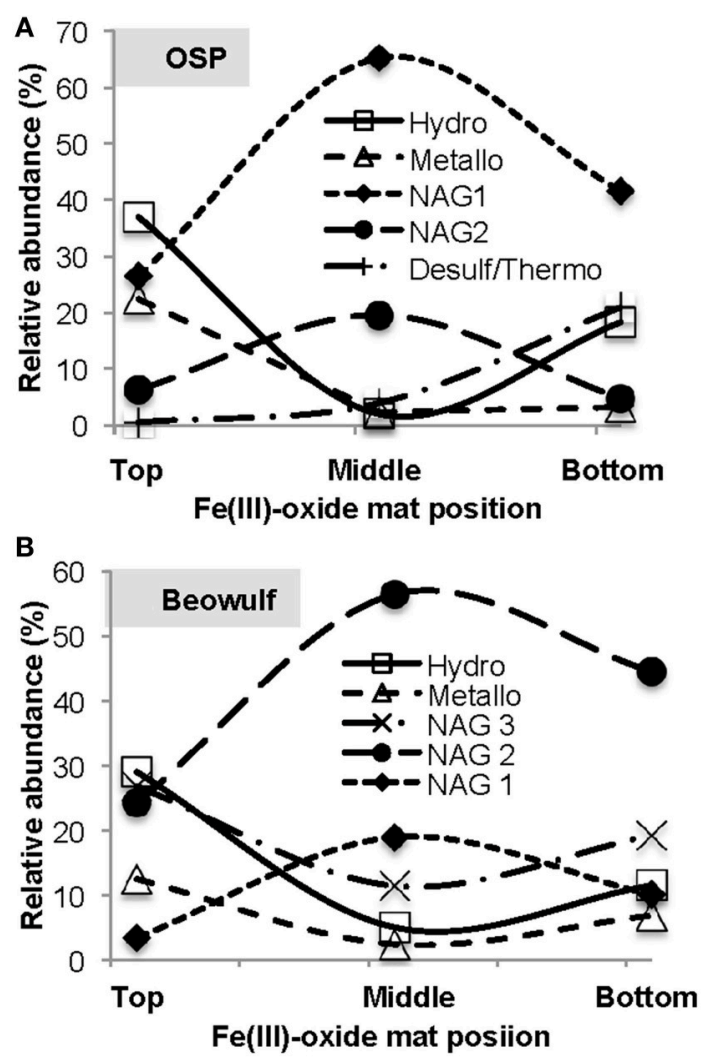

FIGURE 9 | Relative abundance of taxa (16S rRNA gene Illumina barcodes) as a function of depth in mature thermoacidic iron oxide mats from One Hundred Spring Plain (A) and Beowulf (B) Springs. The top position refers to the upper $1 \mathrm{~mm}$ oxygenated zone, the middle position represents depths of $\sim 2-7 \mathrm{~mm}$, and the bottom position represents hypoxic regions $>10 \mathrm{~mm}$.

Continued Fe(III)-oxide accretion and cell growth $>30$ days results in significant accumulation of biomass $C$ and niche diversity (e.g., $\mathrm{O}_{2}$ gradients) that allow for the colonization of heterotrophic archaea (Stage III). Moreover, the probability of trapping exogenous detritus and/or debris from landscape sources increases as the surface roughness increases due to cell growth and $\mathrm{Fe}(\mathrm{III})$-oxide formation. For example, plant material, diatoms, and wind-blown solid-phases can be trapped by the complex series of ridges and valleys established during mat development. The later succession of heterotrophs also suggests that they require specific metabolites and/or cofactors produced by autotrophic populations. The primary archaeal organoheterotrophs observed from 30 to 70 days using iTag analysis (16S rRNA) included members of the candidate phylum Geoarchaeota (Kozubal et al., 2013), novel archaeal Groups 2 and 3 (Inskeep et al., 2010, 2013; Kozubal et al., 2012) and members from two additional Sulfolobales lineages, which have also been observed at these lower abundances (1-2\%) in prior Fe-mat studies (Inskeep et al., 2010; Kozubal et al., 2012). By 70 days, $\mathrm{Fe}(\mathrm{III})$-oxide mat depths can reach 2-4 $\mathrm{mm}$, and have developed initial $\mathrm{O}_{2}$ concentration gradients (Figure 7) that support further niche diversification to include hypoxic populations. Although

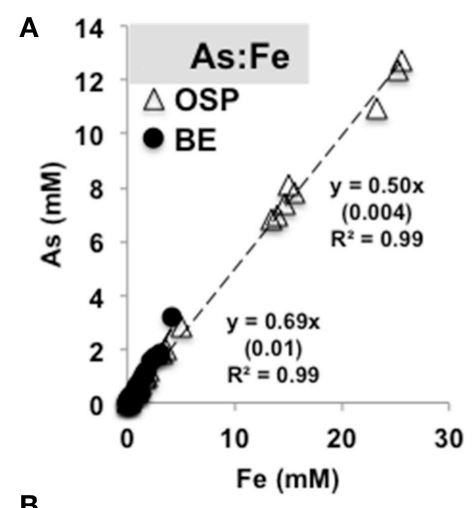

B
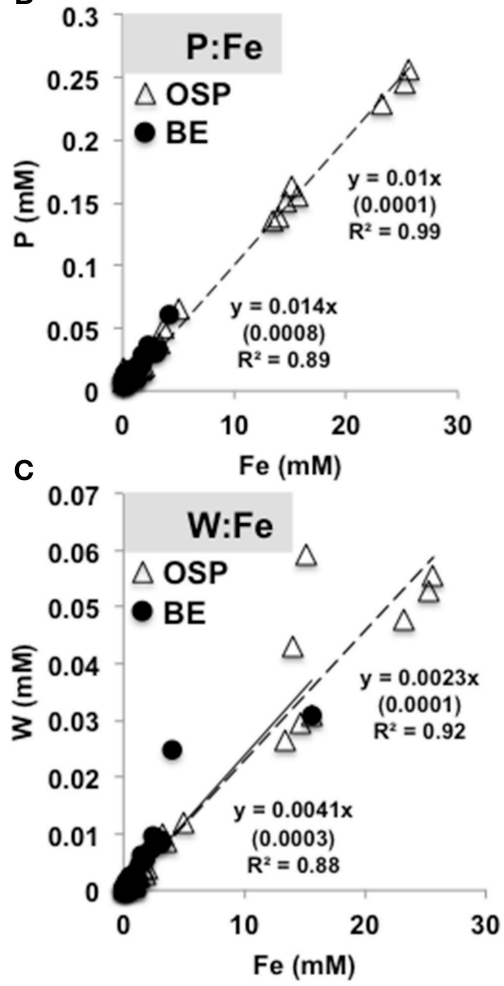

FIGURE 10 | Molar ratios of arsenic (A), phosphorous (B), and tungsten (C) to total solid phase iron extracted from slides incubated in One Hundred Spring Plain (open triangles, dotted black line) and Beowulf (filled circles, black line) Springs (Figure 1). Numbers in parentheses are the standard error.

the fixation of $\mathrm{CO}_{2}$ by autotrophic Hydrogenobaculum spp. and M. yellowstonensis populations represents a significant fraction of the biomass C in "mature" Fe(III)-oxide mats (no less than $\sim 40 \%$ DIC signature; Jennings et al., 2014), the relative abundance of Hydrogenobaculum spp. is actually negatively correlated with $\mathrm{Fe}(\mathrm{III})$-oxide accretion over time (Figures 5, 6) due to the rise of other heterotrophic populations; although Hydrogenobaculum spp. are constantly colonizing and growing in the active $\mathrm{O}_{2}$ consuming layer (i.e., the upper $1 \mathrm{~mm}$ of mat) (Figure 3).

Ultimately, the shallow water depth in the outflow channels $(<2 \mathrm{~cm})$ becomes a limiting factor for the maximum thickness of these Fe(III)-oxide mats (Stage IV). Several metagenomes 


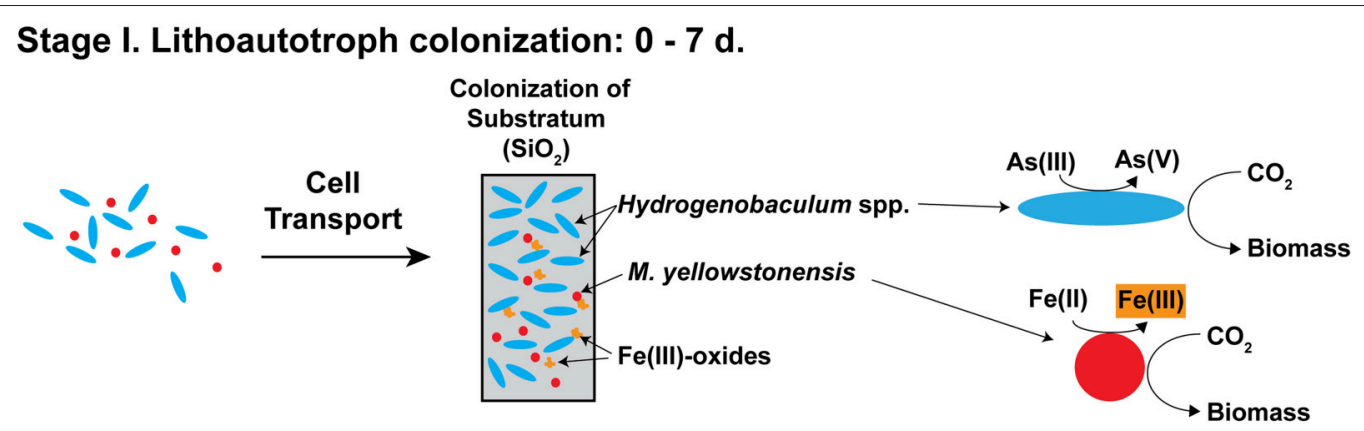

Stage II. $\mathrm{Fe}(\mathrm{III})$-oxide accretion and ridge formation: 7 - $30 \mathrm{~d}$.

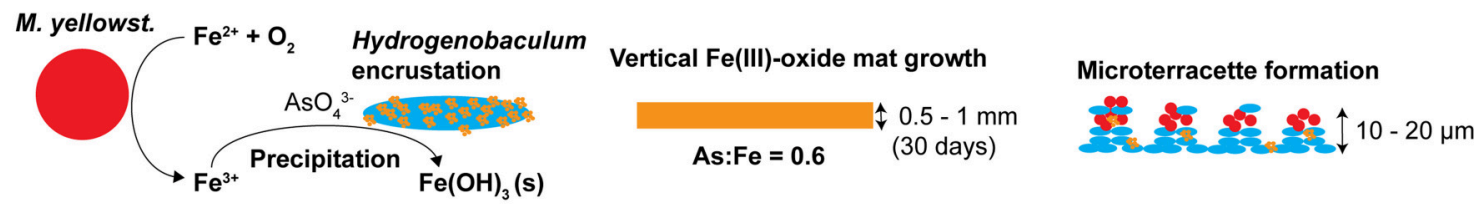

Stage III. Heterotroph colonization and maximum Fe(III)-oxide accretion: 30 - $70 \mathrm{~d}$.
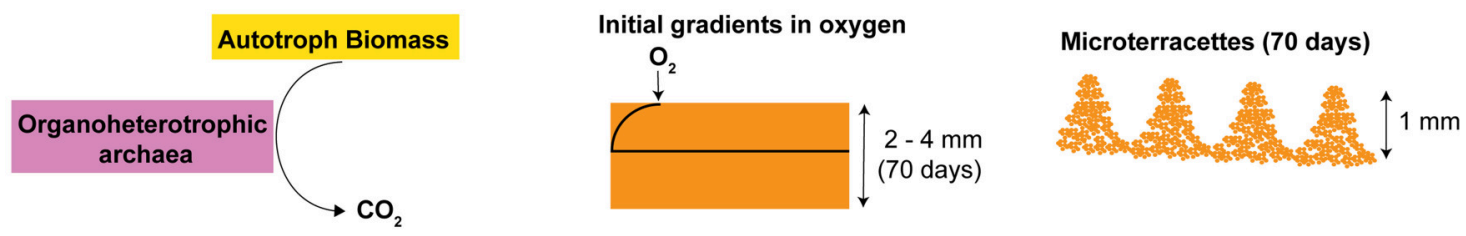

Stage IV. Mature mat formation, steep $\mathrm{O}_{2}$ gradients, niche differentiation: $>70 \mathrm{~d}$.

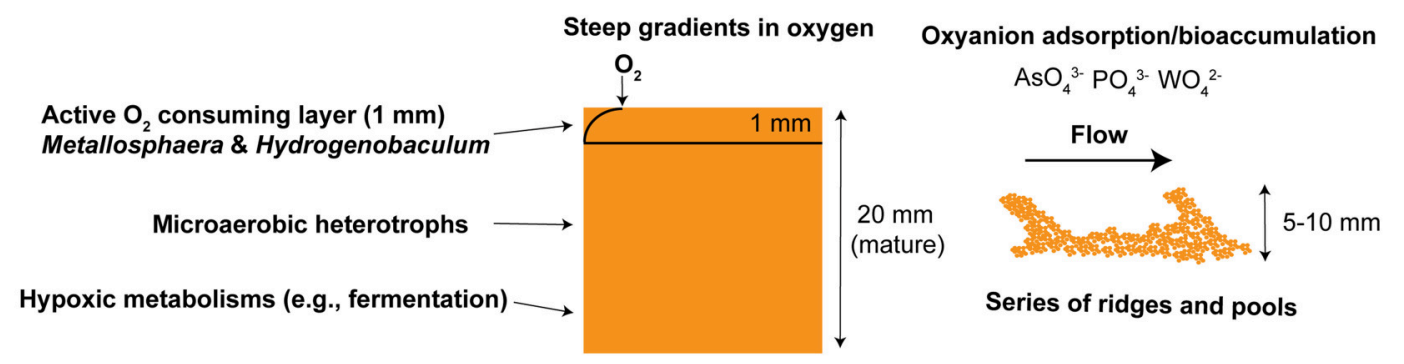

FIGURE 11 | Conceptual model of iron oxide mat development (four stages) in high-temperature, acidic geothermal springs of Yellowstone National Park. Stage I is defined by the primary colonization of lithoautotrophic populations of Hydrogenobaculum spp. and Metallosphaera yellowstonensis. Stage II is represented by visible iron oxide accretion, encrustation of Hydrogenobaculum spp. by Fe(III)-oxides, and initial formation of microterracettes. Heterotrophic archaea begin colonizing in Stage III and gradients in $\mathrm{O}_{2}$ are apparent. As iron oxide depth increases to form "mature" $0.5-2 \mathrm{~cm}$ thick mats (Stage IV) the microbial community undergoes succession toward organoheterotrophic archaea, where steep gradients in oxygen, and macroscale ridges and pools are observed.

were obtained from "mature" Fe(III)-oxide mats of this thickness in both spring positions used in the current study, and these samples were also analyzed using iTags (Table 2). The integration and comparison of these datasets with the temporal incubation studies provides an opportunity to understand the cycle of Fe(III)-oxide mat development. Larger microterracettes $(\sim 1 \mathrm{~mm})$, which are visible even after $\sim 70$ days (Figure 8), continue to grow to form a series of centimeter-scale terracettes over a temperature range of $\sim 55-75^{\circ} \mathrm{C}$ (Figure 1). These thicker $\mathrm{Fe}(\mathrm{III})$-oxide terracettes reveal changes in population abundance as a function of mat depth (Figure 9) that are consistent with expected gradients in $\mathrm{O}_{2}$ observed in "mature" mats (Figure 7).
The succession of early colonizing autotrophs to later colonizing heterotrophs is directly applicable to other Fe(III)-oxide mat hot spring ecosystems; autotroph-heterotroph successional patterns are a common theme in other microbial mat communities, as well as larger-scale ecosystems (Odum, 1969).

High-temperature Fe(III)-oxide mats of Norris Geyser Basin are modern-day stromatolites (Riding, 1999), which form as a direct consequence of microbial metabolism and associated hydrogeochemical controls. The preferential biomineralization of Fe(III)-oxides on cell surfaces of Hydrogenobaculum spp. may be related to enhanced nucleation rates of poorly-crystalline $\mathrm{Fe}$ (III)-oxide phases. Other members of the Aquificales are also 
thought to promote the nucleation and growth of aragonite $\left(\mathrm{CaCO}_{3}\right.$; Kandianis et al., 2008; Fouke, 2011). Stable carbon isotopes (i.e., ${ }^{13} \mathrm{C}$ ) also provide signatures indicative of biological activity, such as evidence for significant $\mathrm{CO}_{2}$ fixation in extant $\mathrm{Fe}$ (III)-oxide mats (Jennings et al., 2014). Micro-morphological changes across different stages of $\mathrm{Fe}$ (III)-oxide mat development including cell encrustation by Fe(III)-oxides and the formation of microterracettes also reveal microbiological signatures that may provide a reference for comparison to other extant and ancient $\mathrm{Fe}(\mathrm{III})$-oxide hot spring ecosystems on Earth, or Fe(III)-oxide mineral deposits identified on other planetary systems such as Mars (Madden et al., 2004).

\section{AUTHOR CONTRIBUTIONS}

JB and WI conceived and designed experiments. JB, HB, ZJ, $\mathrm{MK}, \mathrm{RJ}$, and WI performed experiments. ST contributed Illumina sequencing and support. JB, HB, ZJ, and WI analyzed data. JB and WI wrote the manuscript.

\section{ACKNOWLEDGMENTS}

This work was supported by the Department of Energy (DOE)Pacific Northwest National Laboratory Foundational Science Focus Area in Biological Interactions (subcontract 112443), the DOE-Joint Genome Institute Community Sequencing Projects (CSP 787081 and 787701), and the National Science FoundationIntegrative Graduate Education and Training Program (DGE

\section{REFERENCES}

Ackerman, G. G. (2006). Biogeochemical Gradients and Energetics in Geothermal Systems of Yellowstone National Park. Master of Science thesis, Montana State University, Montana State University.

Beam, J., Jay, Z., Kozubal, M., and Inskeep, W. (2014). Niche specialization of novel Thaumarchaeota to oxic and hypoxic acidic geothermal springs of Yellowstone National Park. ISME J. 8, 938-951. doi: 10.1038/ismej. 2013.193

Berg, I. A., Kockelkorn, D., Buckel, W., and Fuchs, G. (2007). A 3hydroxypropionate/4-hydroxybutyrate autotrophic carbon dioxide assimilation pathway in archaea. Science 318, 1782-1786. doi: 10.1126/science.1149976

Bernstein, H. C., Beam, J. P., Kozubal, M. A., Carlson, R. P., and Inskeep, W. P. (2013). In situ analysis of oxygen consumption and diffusive transport in high-temperature acidic iron-oxide microbial mats. Environ. Microbiol. 15, 2360-2370. doi: 10.1111/1462-2920.12109

Boyd, E. B., Leavitt, W. D., and Geesey, G. G. (2009). $\mathrm{CO}_{2}$ uptake and fixation by a thermoacidophilic microbial community attached to precipitated elemental sulfur in a geothermal spring. Appl. Environ. Microbiol. 75, 4289-4296. doi: 10.1128/AEM.02751-08

Caporaso, J. G., Lauber, C. L., Walters, W. A., Berg-Lyons, D., Lozupone, C. A., Turnbaugh, P. J., et al. (2010). Global patterns of 16S rRNA diversity at a depth of millions of sequences per sample. Proc. Natl. Acad. Sci. U.S.A. 108, 4516-4522. doi: 10.1073/pnas.1000080107

de Beer, D., Stoodley, P., Roe, F., and Lewandowski, Z. (1994). Effects of biofilm structures on oxygen distribution and mass-transport. Biotechnol. Bioenerg. 43, 1131-1138. doi: 10.1002/bit.260431118

Denef, V., Mueller, R., and Banfield, J. (2010). AMD biofilms: using model communities to study microbial evolution and ecological complexity in nature. ISME J. 4, 599-610. doi: 10.1038/ismej.2009.158

D'Imperio, S., Lehr, C., Breary, M., and McDermott, T. (2007). Autecology of an arsenite chemolithotroph: sulfide constraints on function and distribution
0654336) (fellowship support to JB, HB, ZJ, and RJ). The work conducted by the U.S. Department of Energy Joint Genome Institute, a DOE Office of Science User Facility, is supported by the Office of Science of the U.S. Department of Energy under Contract No. DE-AC02-05CH11231. HB is also grateful for support from the Linus Pauling Distinguished Postdoctoral Fellowship, a Laboratory Directed Research and Development Program at PNNL. JB appreciates assistance from M. Wagner and M. Schmid (University of Vienna) for FISH training, C. Hendrix and S. Gunther (YNP Center for Resources) for research permitting in YNP (YELL-SCI-5068), C. Carey and A. Mazurie (MSU) for iTag data processing, and B. Pitts (MSU) for instruction and helpful comments on confocal microscopy. FISH images were taken at microscope facilities in the Center for Biofilm Engineering (Montana State University), which is supported by the NSF-MRI Program and the M.J. Murdock Charitable Trust. JB and WI appreciate helpful comments and discussion with E. N. J. Brookshire, B. W. Fouke, and M. W. Fields. The authors also appreciate the comments of an anonymous reviewer that improved the quality of the final manuscript.

\section{SUPPLEMENTARY MATERIAL}

The Supplementary Material for this article can be found online at: http://journal.frontiersin.org/article/10.3389/fmicb. 2016.00025

in a geothermal spring. Appl. Environ. Microbiol. 73, 7067-7074. doi: 10.1128/AEM.01161-07

D’Imperio, S., Lehr, C. R., Oduro, H., Druschel, G., Kühl, M., and McDermott, T. R. (2008). Relative Importance of $\mathrm{H}_{2}$ and $\mathrm{H}_{2} \mathrm{~S}$ as Energy Sources for Primary Production in Geothermal Springs. Appl. Environ. Microbiol. 74, 5802-5808. doi: 10.1128/AEM.00852-08

Donahoe-Christiansen, J., D’Imperio, S., Jackson, C., Inskeep, W., and McDermott, T. (2004). Arsenite-oxidizing Hydrogenobaculum strain isolated from an acid-sulfate-chloride geothermal spring in Yellowstone National Park. Appl. Environ. Microbiol. 70, 1865-1868. doi: 10.1128/AEM.70.3.1865-1868.2004

Ehrlich, H. L., and Newman, D. K. (2009). "Geomicrobiology of iron," in Geomicrobiology, 5th Edn. eds H. L. Ehrlich and D. K. Newman (New York, NY: CRC Press; Taylor and Francis Group, LLC), 279-329.

Emerson, D. (2012). Biochemistry and microbiology of microaerobic Fe(II) oxidation. Biochem. Soc. Trans. 40, 1211-1216. doi: 10.1042/BST201 20154

Emerson, D., and Revsbech, N. P. (1994). Investigation of an iron-oxidizing microbial mat community located near Aarhus, Denmark: field studies. Appl. Environ. Microbiol. 60, 4022-4031.

Fouke, B. (2011). Hot-spring Systems Geobiology: abiotic and biotic influences on travertine formation at Mammoth Hot Springs, Yellowstone National Park, USA. Sedimentology 58, 170-219. doi: 10.1111/j.1365-3091.2010.01209.x

Fournier, R. O. (1989). Geochemistry and dynamics of the Yellowstone National Park hydrothermal system. Ann. Rev. Earth Planet. Sci. 17, 13-53. doi: 10.1146/annurev.ea.17.050189.000305

Hamamura, N., Macur, R. E., Korf, S., Ackerman, G., Taylor, W. P., Kozubal, M., et al. (2009). Linking microbial oxidation of arsenic with detection and phylogenetic analysis of arsenite oxidase genes in diverse geothermal environments. Environ. Microbiol. 11, 421-431. doi: 10.1111/j.1462-2920.2008.01781.x

Hanert, V. H. (1974). In situ-untersuchungen zur analyse und intensitat der Eisen(III)-fallung in dranungen. $Z f$ Kulturtechnik und Flurbereinigung 15, 80-90. 
Inskeep, W., Macur, R., Harrison, G., Bostick, B., and Fendorf, S. (2004). Biomineralization of As(V)-hydrous ferric oxyhydroxide in microbial mats of an acid-sulfate-chloride geothermal spring, Yellowstone National Park. Geochim. Cosmochim. Acta 68, 3141-3155. doi: 10.1016/j.gca.2003.09.020

Inskeep, W., Rusch, D., Jay, Z., Herrgard, M., Kozubal, M., Richardson, T., et al. (2010). Metagenomes from high-temperature chemotrophic systems reveal geochemical controls on microbial community structure and function. PLoS ONE 5:e9773. doi: 10.1371/journal.pone.0009773

Inskeep, W. P., Ackerman, G. A., Taylor, W. P., Kozubal, M. A., Korf, S., and Macur, R. E. (2005). On the energetics of chemolithotrophy in nonequilibrium systems: case studies of geothermal springs in Yellowstone National Park. Geobiology 3, 297-317. doi: 10.1111/j.1472-4669.2006.00059.x

Inskeep, W. P., Jay, Z. J., Herrgard, M. J., Kozubal, M. A., Rusch, D. B., Tringe, S. G., et al. (2013). Phylogenetic and functional analysis of metagenome sequence from high-temperature archaeal habitats demonstrate linkages between metabolic potential and geochemistry. Front. Microbiol. 4:95. doi: 10.3389/fmicb.2013.00095

Inskeep, W. P., and McDermott, T. R. (2005). "Geomicrobiology of acid-sulfatechloride springs in Yellowstone National Park," in Geothermal Biology and Geochemistry in Yellowstone National Park, eds W. P. Inskeep and T. R. McDermott (Bozeman, Mt: Montana State University Publications), 143-162.

Jackson, C. R., Langner, H. W., Donahoe-Christiansen, J., Inskeep, W. P., and McDermott, T. R. (2001). Molecular analysis of microbial community structure in an arsenite-oxidizing acidic thermal spring. Environ. Microbiol. 3, 532-542. doi: 10.1046/j.1462-2920.2001.00221.x

Jay, Z., Rusch, D., Tringe, S., Bailey, C., Jennings, R., and Inskeep, W. (2014). Predominant Acidilobus-like populations from geothermal environments in Yellowstone National Park exhibit similar metabolic potential in different hypoxic microbial communities. Appl. Environ. Microbiol. 80, 294-305. doi: 10.1128/AEM.02860-13

Jennings, R., Whitmore, L., Moran, J., Kreuzer, H., and Inskeep, W. (2014). Carbon dioxide fixation by Metallosphaera yellowstonensis and acidothermophilic ironoxidizing microbial communities from Yellowstone National Park. Appl. Environ. Microbiol. 80, 2665-2671. doi: 10.1128/AEM.03416-13

Kandianis, M. T., Fouke, B. W., Johnson, R. W., Veysey, J., and Inskeep, W. P. (2008). Microbial biomass: a catalyst for the $\mathrm{CaCO} 3$ precipitation in advection-dominated transport regimes. Geol. Soc. Am. Bull. 120, 442-450. doi: 10.1130/B26188.1

Kappler, A., and Straub, K. L. (2005). Geomicrobiological cycling of iron. Rev. Mineral. Geochem. 59, 85-108. doi: 10.2138/rmg.2005.59.5

Karl, D. M., McMurtry, G. M., Malahoff, A., and Garcia, M. O. (1988). Loihi Seamount, Hawaii: a mid-plate volcano with a distinctive hydrothermal system. Nature 335, 532-535. doi: 10.1038/335532a0

Kletzin, A., and Adams, M. W. W. (1996). Tungsten in biological systems. FEMS Microbiol. Rev. 18, 5-63. doi: 10.1111/j.1574-6976.1996.tb00226.x

Konhauser, K. (1998). Diversity of bacterial iron mineralization. Earth Sci. Rev. 43, 91-121. doi: 10.1016/S0012-8252(97)00036-6

Konhauser, K. (ed.). (2006). "Biomineralization," in Introduction to Geomicrobiology (Oxford: Blackwell Science Ltd.), 139-149.

Kozubal, M. A., Dlakić, M., and Inskeep, W. P. (2011). Terminal oxidase diversity and function in "Metallosphaera yellowstonensis": gene expression and protein modeling suggest mechanisms of Fe(II) oxidation in Sulfolobales. Appl. Environ. Microbiol. 77, 1844-1853. doi: 10.1128/AEM.01646-10

Kozubal, M. A., Macur, R. E., Jay, Z. J., Beam, J. P., Malfatti, S. A., Tringe, S. G., et al. (2012). Microbial iron cycling in acidic geothermal springs of Yellowstone National Park: integrating molecular surveys, geochemical processes, and isolation of novel Fe-active microorganisms. Front. Microbiol. 3:109. doi: 10.3389/fmicb.2012.00109

Kozubal, M. A., Macur, R. E., Korf, S., Taylor, W. P., Ackermann, G. G., Nagy, A., et al. (2008). Isolation and distribution of a novel iron-oxidizing crenarchaeon from acidic geothermal springs in Yellowstone National Park. Appl. Environ. Microbiol. 74, 942-949. doi: 10.1128/AEM.01200-07

Kozubal, M. A., Romine, M., Jennings Rde, M., Jay, Z. J., Tringe, S. G., Rusch, D. B., et al. (2013). Geoarchaeota: a new candidate phylum in the Archaea from hightemperature acidic iron mats in Yellowstone National Park. ISME J. 7, 622-634. doi: 10.1038 /ismej.2012.132

Kubo, K., Knittel, K., Amann, R., Fukui, M., and Matsuura, K. (2011). Sulfurmetabolizing bacterial populations in microbial mats of the Nakausa hot spring, Japan. Syst. Appl. Microbiol. 34, 293-302. doi: 10.1016/j.syapm.2010. 12.002

Langner, H., Jackson, C., McDermott, T., and Inskeep, W. (2001). Rapid oxidation of arsenite in a hot spring ecosystem, Yellowstone National Park. Environ. Sci. Technol. 35, 3302-3309. doi: 10.1021/es0105562

Leblanc, M., Achard, B., Othman, D. B., Luck, J. M., Bertrand-Sarfati, J., and Personné, J. C. (1996). Accumulation of arsenic from acidic mine waters by ferruginous bacterial accretions (stromatolites). Appl. Geochem. 11, 541-554. doi: 10.1016/0883-2927(96)00010-8

Loeppert, R. H., and Inskeep, W. P. (1996). "Iron," in Methods of Soil Analysis: Part 3 Chemical Methods, ed J. M. Bartels (Madison, WI: Soil Science Society of America and American Society of Agronomy), 639-664.

Macur, R. E., Langner, H. W., Kocar, B. D., and Inskeep, W. P. (2004) Linking geochemical processes with microbial community analysis: successional dynamics in an arsenic-rich, acid-sulphate-chloride geothermal spring. Geobiology 2, 163-177. doi: 10.1111/j.1472-4677.2004. 00032.x

Madden, M. E. E., Bodnar, R. J., and Rimstidt, J. D. (2004). Jarosite as an indicator of water-limited weathering on Mars. Nature 431, 821-823. doi: 10.1038 /nature02971

Mann, S. (1988). Molecular recognition in biomineralization. Nature 332, 119-124. doi: $10.1038 / 332119 \mathrm{a} 0$

Odum, E. P. (1969). The strategy of ecosystem development. Science 164, 262-270. doi: $10.1126 /$ science.164.3877.262

Okegbe, C., Price-Whelan, A., and Dietrich, L. E. P. (2014). Redox-driven regulation of microbial community morphogenesis. Curr. Opin. Microbiol. 18, 39-45. doi: 10.1016/j.mib.2014.01.006

Oksanen, J., Blanchet, F. G., Kindt, R., Legendre, P., Minchin, P. R., O’Hara, R. B., et al. (2016). Community Ecology Package. Available online at: https://github. com/vegandevs/vegan

Peters, K. E., and Moldowan, J. M. (1993). The Biomarker Guide: Interpreting Molecular Fossils in Petroleum and Ancient Sediments. Upper Saddle River, NJ: Prentice Hall.

Reid, R. P., Visscher, P. T., Decho, A. W., Stolz, J. F., Bebout, B. M., Dupraz, C., et al. (2000). The role of microbes in accretion, lamination and early lithification of modern marine stromatolites. Nature 406, 989-992. doi: 10.1038/350 23158

Riding, R. (1999). The term stromatolite: towards an essential definition. Lethaia 32, 321-330. doi: 10.1111/j.1502-3931.1999.tb00550.x

Romano, C., D’Imperio, S., Woyke, T., Mavromatis, K., Lasken, R., Shock, E., et al. (2013). Comparative genomic analysis of phylogenetically closely related Hydrogenobaculum sp. isolates from Yellowstone National Park. Appl. Environ. Microbiol. 79, 2932-2943. doi: 10.1128/AEM.03591-12

Singer, P. C., and Stumm, W. (1970). Acidic mine drainage: rate-determining step. Science 167, 1121-1123. doi: 10.1126/science.167.3921.1121

Stahl, D. A., and Amann, R. (1991). "Development and application of nucleic acid probes in bacterial systematics," in Nucleic Acid Techniques in Bacterial Systematics, eds E. Stackebrandt and M. Goodfellow (Chichester: Wiley \& Sons Ltd.), 205-248.

Takacs-Vesbach, C., Inskeep, W. P., Jay, Z. J., Herrgard, M., Rusch, D. B., Tringe, S. G., et al. (2013). Metagenome sequence analysis of filamentous microbial communities obtained from geochemically distinct geothermal channels reveals specialization of three Aquificales lineages. Front. Microbiol. 4:84. doi: $10.3389 /$ fmicb.2013.00084

Thiele, E. W. (1939). Relation between catalytic activity and size of particle. Industr. Eng. Chem. 31, 916-920. doi: 10.1021/ie50355a027

Conflict of Interest Statement: The authors declare that the research was conducted in the absence of any commercial or financial relationships that could be construed as a potential conflict of interest.

Copyright (c) 2016 Beam, Bernstein, Jay, Kozubal, Jennings, Tringe and Inskeep. This is an open-access article distributed under the terms of the Creative Commons Attribution License (CC BY). The use, distribution or reproduction in other forums is permitted, provided the original author(s) or licensor are credited and that the original publication in this journal is cited, in accordance with accepted academic practice. No use, distribution or reproduction is permitted which does not comply with these terms. 